The politics of bureaucratic 'pockets of effectiveness': Insights from Ghana's Ministry of Finance ${ }^{1}$

\title{
Abdul-Gafaru Abdulai*
}

Giles Mohan ${ }^{* *}$

June 2019

* University of Ghana Business School, Legon, Accra

Email correspondence: agabdulai@ug.edu.gh or ghaaff2000@yahoo.co.uk

${ }^{* *}$ The Open University, UK

Email correspondence: giles.mohan@open.ac.uk

ISBN: 978-1-912593-21-7

${ }^{1}$ This paper was produced for the ESRC-DFID project, 'Investigating Pockets of Effectiveness in Developing Countries: A New Route to Building State Capacity for Development'. 


\begin{abstract}
Ghana's Ministry of Finance (MoF) has been identified as a 'pocket of effectiveness', both in relation to other state agencies and in terms of delivering on its mandate. However, this effectiveness has not been constant over the post-independence period, which requires us to explain how and why effectiveness is generated, but also why it can falter. We argue that the effectiveness of the MoF's performance derives from the coupling of changing features in Ghana's wider political settlement with the internal organisational features of this key ministry. Using historical analysis and data collected from recent interviews and reports, we focus on the MoF's performance over the past five years, even as we situate this in the longer-term context of the Ministry's ups and downs.
\end{abstract}

Keywords: Ghana, pockets of effectiveness, Ministry of Finance, politics, political settlements

Abdulai, A.-G. and Mohan, G. (2019) The politics of bureaucratic 'pockets of effectiveness': Insights from Ghana's Ministry of Finance. ESID Working Paper No. 119. Manchester, UK: The University of Manchester. Available at www.effectivestates.org

This document is an output from a project funded by UK Aid from the UK government for the benefit of developing countries. However, the views expressed and information contained in it are not necessarily those of, or endorsed by the UK government, which can accept no responsibility for such views or information or for any reliance placed on them. 


\title{
1. Introduction
}

While Ghana has been hailed as a democratic success story, its state institutions have a mixed record and some of the latest governance indicators even point to a declining trend. ${ }^{2}$ One observer characterises Ghana's public administration system as one 'that does not work and which severely reduces the ability of the government to implement reforms and programs' (Whitfield, 2010: 735, see also Killick, 2008; IMANI, 2018). Ansu (2013) explains this problem as essentially the product of the incentives generated by the competitive character of clientelist politics in Ghana:

\begin{abstract}
'State capacity in Ghana is weak. The main reason for this is not the lack of competent Ghanaians or poor remuneration. In large part, it is due to a partisan political environment that produces a large turnover of senior staff and technocrats whenever governments change, as they do in Ghana. This undermines professionalism, continuity, long-term planning orientation, learning and innovation in the public service' (Ansu 2013: 512).
\end{abstract}

This observation points to the wider political settlement (PS) as largely responsible for the poor performance. Indeed the 'partisan political environment' seems to have intensified, with ruling elites becoming 'more preoccupied with retaining power' (IMANI 2018: 15), which filters through to a range of practices that undermine the effectiveness of the public bureaucracy.

However, amidst this general weakness of the Ghanaian public bureaucracy, evidence suggests that the Ministry of Finance (MoF) has maintained a relatively high degree of performance during the past three decades, although with substantial variations over time. Such relatively good performance of state institutions within a wider institutional malaise has been termed 'pockets of effectiveness' (Roll, 2014a) and here we seek to explain the emergence and sustenance of this relatively good performance, as well as the changes over time. Ansu's analysis outlined above suggests that the performance of MoF is explained in broad terms by the coupling of structures within Ghana's wider political settlement with more 'internal' organisational factors. In particular, we argue that this coupling of structural and organisational factors has hinged over time on questions of elite cohesion within the ruling coalition and the subsequent relationships between the executive and senior bureaucrats in MoF. Additionally, the role of donors has been important in shaping the incentives, capacity and sanctions that have shaped MoF's performance.

The paper addresses three related questions: why and how has the Ministry of Finance maintained a relatively high level of effectiveness in the performance of its mandated functions? What role has Ghana's political settlement dynamics played in shaping the Ministry's performance? What accounts for the substantial variations in the relative effectiveness of the Ministry, both within and across different ruling

\footnotetext{
${ }^{2}$ For example, see the Ibrahim Index on African Governance: http://mo.ibrahim.foundation/iiag/.
} 
coalitions? We are primarily interested in the more recent performance of MoF, which observers suggested has entered another period of relative decline, but, in order to understand the wider political settlement, it is necessary to take a longer historical perspective to understand how and when structures were put in place and how they condition contemporary political dynamics.

Data for this paper is based on a wide range of sources, including a review of relevant academic literature and statistical data, official government reports, newspaper articles, an expert survey undertaken with 27 respondents in Accra, and 30 in-depth interviews with key informants, 20 of whom have had direct experience in working with the MoF. Most of these interviews were conducted between May and June 2018.

Our argument is structured as follows. Section 2 outlines the empirical case for Ghana's MoF to be considered a pocket of effectiveness (hereafter PoE). Here we use published studies, official data, and the results of our expert survey. Section 3 then briefly outlines the PS framework, and summarises Ghana's changing political settlements since independence, though we focus most on the recent period. Here we are concerned with how Ghana's PS has shaped institutional performance in general and that of the MoF in particular. Section 4 then examines the organisational factors within the MoF that are, in some cases, relatively autonomous from the PS and, in other cases, shaped quite directly by it. Section 5 summarises the findings and provides some tentative concluding thoughts.

\section{Is the Ministry of Finance a pocket of effectiveness?}

PoEs are judged in terms of their relative performance vis-à-vis other state agencies and with respect to delivering their mandated functions. The main mission of MoF is to ensure macroeconomic stability and promote sustainable economic growth. As such, its core objectives are to formulate and implement sound macroeconomic policies; prepare and implement the annual budget; pursue prices and exchange rate stability; reduce and restructure the domestic debt and ensure the sustainability of public debt; improve fiscal resource mobilisation and public expenditure management; and allocate and manage financial resources efficiently. ${ }^{3}$

For most of the last three decades, Ghana's economy has been on a high growth path, especially since 2001. Per capita growth rates averaged more than 2.5 percent between 1983 and 2006, and increased to around 6 percent from 2006 to 2011 (Jose Silverio and Maddalena, 2016). Indeed, Ghana has grown more quickly, not only than most other African economies since 2008, but also than the average among lower middle-income countries since 2010 (Molini and Paci, 2015). However, as Figure 1 shows, economic growth in post-colonial Ghana has been highly erratic, with the country experiencing a significant economic downturn in the 1970 s and early 1980s. From 1984 onwards, however, economic growth began to stabilise, picking up quite strongly since 2001, though with some dips. Growth peaked at 14 percent in

\footnotetext{
${ }^{3}$ See: https://www.mofep.gov.gh/about-mof (accessed 3 June 2019).
} 


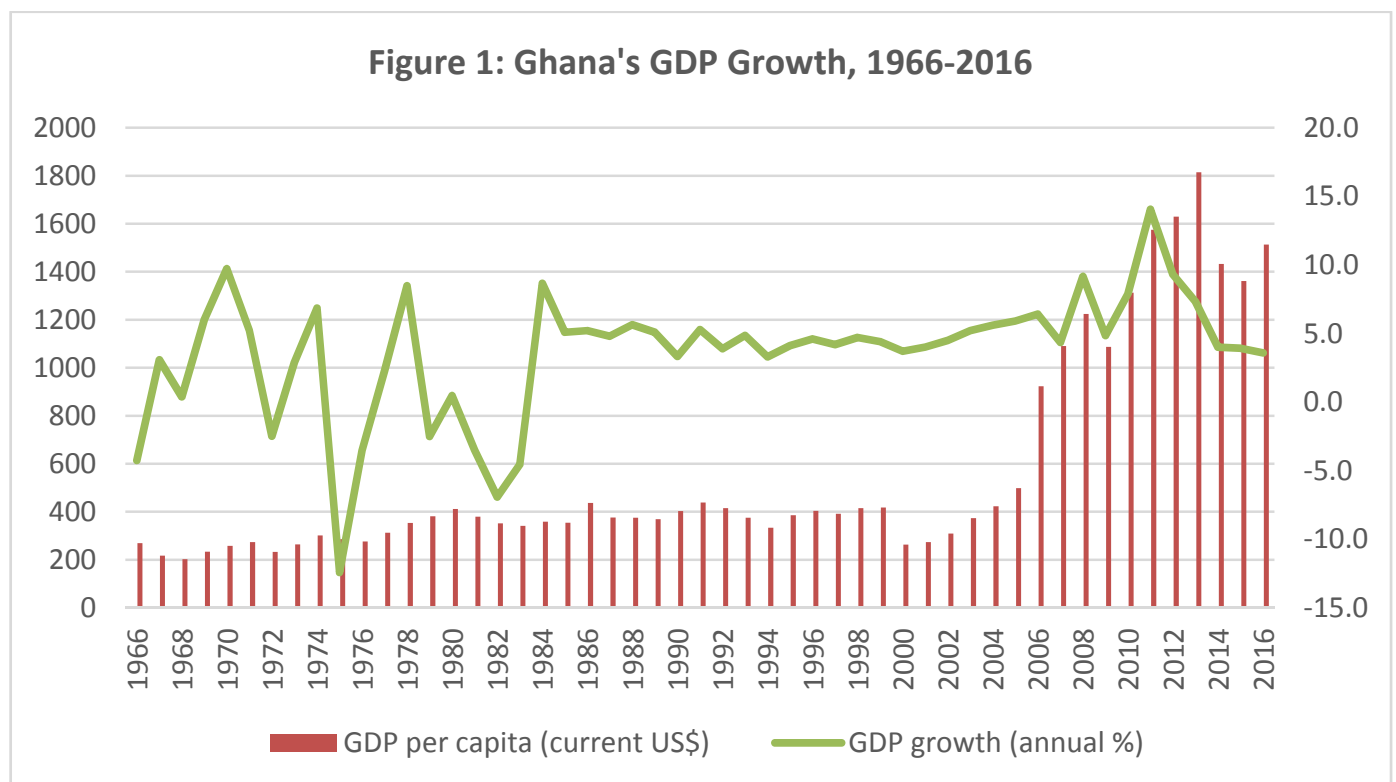

Source: World Development Indicators

2011, before dropping to less than 4 percent in both 2015 and 2016 - the worst recorded in nearly two decades.

Inflation control, a shared responsibility between the MoF and the Bank of Ghana, has been largely kept in check (see Figure 2), and domestic revenue as a proportion of GDP has recorded marginal improvements in the last decade-and-a-half. Data from the Ibrahim Index on African Governance (IIAG) rates Ghana above Uganda, Rwanda and Zambia in the area of domestic revenue mobilisation (see Appendix I). However, performance seems to vary widely across functions, with less impressive outcomes in the areas of public expenditure management and budget controls,

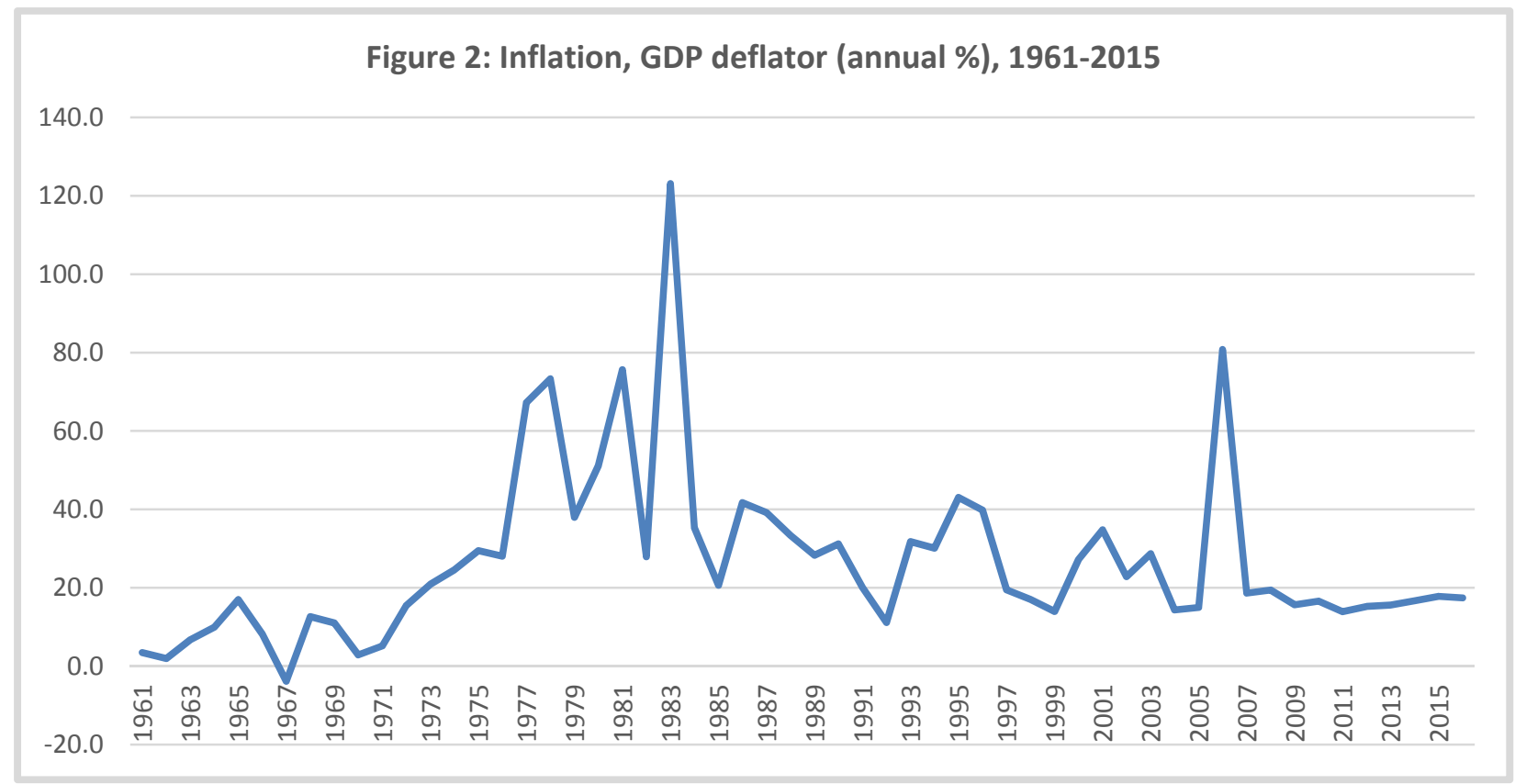

Source: World Development Indicators. 
especially around election years. We show below that this weakness results mainly from the competitive character of clientelist politics in Ghana.

Judged against its objective of preparing and implementing the annual budget, the effectiveness of the MoF is also confirmed by evidence from the Open Budget Surveys $^{4}$ (see Table 1 and Figure 3), which identify Ghana as 'the regional leader on budget oversight and engagement in West Africa' (International Budget Partnership, 2012: 3), while the country has consistently ranked among the top five best performers in Africa. Both the executive's budget proposal and the actual enacted budget have been repeatedly assessed by the International Budget Partnership (IBP) as 'fairly comprehensive' (IBP, 2008: 1; 2010: 2).

Table 1: OBI scores for Ghana and selected regions, 2006-2017

\begin{tabular}{|l|l|l|l|l|l|l|l|}
\hline & $\mathbf{2 0 0 6}$ & $\mathbf{2 0 0 8}$ & $\mathbf{2 0 1 0}$ & $\mathbf{2 0 1 2}$ & $\mathbf{2 0 1 5}$ & $\mathbf{2 0 1 7}$ & $\begin{array}{l}\mathbf{2 0 0 6 - 2 0 1 7} \\
\text { average }\end{array}$ \\
\hline Global average & 46 & 38 & 42 & 43 & 45 & 42 & 42.7 \\
\hline Ghana's score & 42 & 50 & 54 & 50 & 51 & 50 & 49.5 \\
\hline Sub-Saharan Africa & 39 & 23 & 29 & 31 & 39 & 25 & 31.0 \\
\hline West Africa & 31 & 17 & 20 & 26 & 39 & 32 & 27.5 \\
\hline
\end{tabular}

Source: Compiled from various OBI surveys and reports.

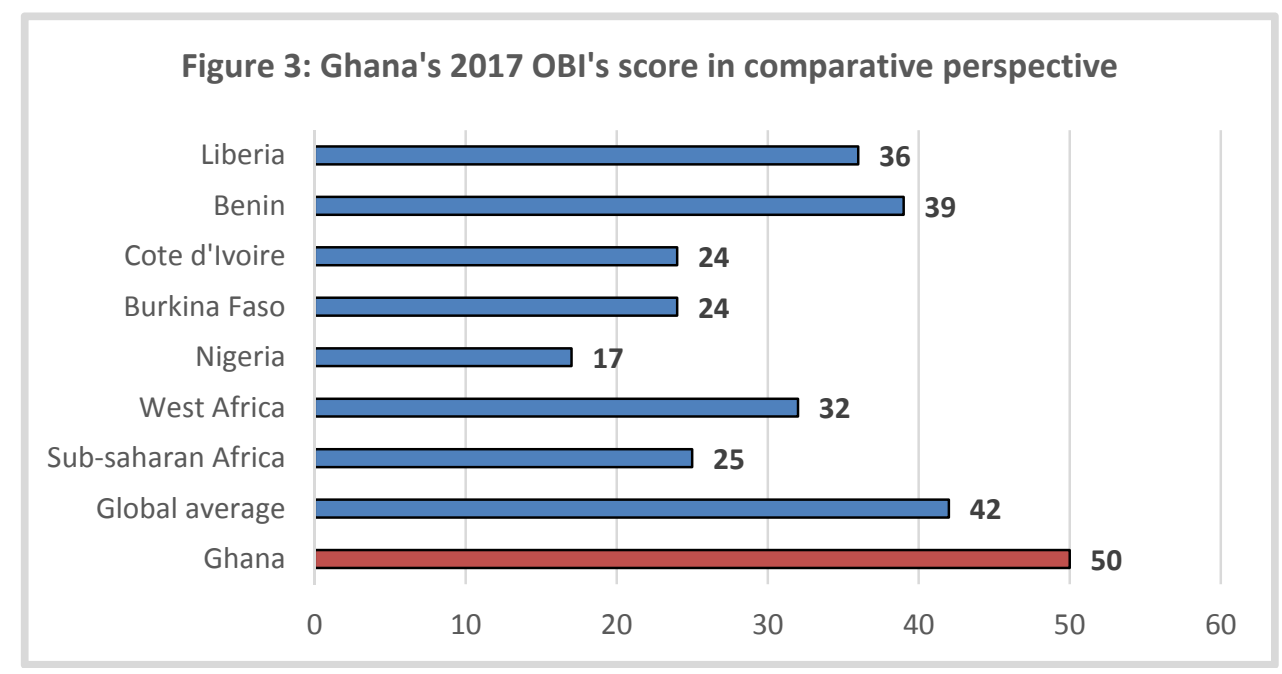

Source: Based on Ghana's OBI scores.

Despite a small recent decline, Table 1 shows that Ghana's 2017 score of 50 was twice the average for sub-Saharan Africa (25) and higher than the global average of 42. Indeed, in the last five consecutive surveys conducted between 2008 and 2017,

\footnotetext{
${ }^{4}$ Conducted by the International Budget Partnership (IBP) every two years since 2006, the OBS assesses whether central governments make 'eight key budget documents available to the public in a timely manner and whether the information contained in these documents is comprehensive and useful' https://www.internationalbudget.org/open-budgetsurvey/downloads/ accessed 3 June 2019). Countries covered by the OBS are given a transparency score of between 0 and 100, which is then used to construct an Open Budget Index $(\mathrm{OBI})$ for each participating country.
} 
Ghana's OBI score consistently exceeded the average scores for West Africa, subSaharan Africa and the world. However, evidence from the Public Expenditure and Financial Accountability (PEFA) surveys shows that Ghana is far from being a star performer, as several key PEFA dimensions have been rated with grades Cs and Ds. Having inherited growth rate of 3.7 percent in 2000, GDP increased consistently (albeit modestly) throughout the leadership of Osafo Maafo, reaching 5.9 percent by 2005. Ghana's 'fiscal policy' score on the IIAG improved during this period (Figure 4), and there was relatively good performance in a wide range of PEFA's indicators (Table 2).

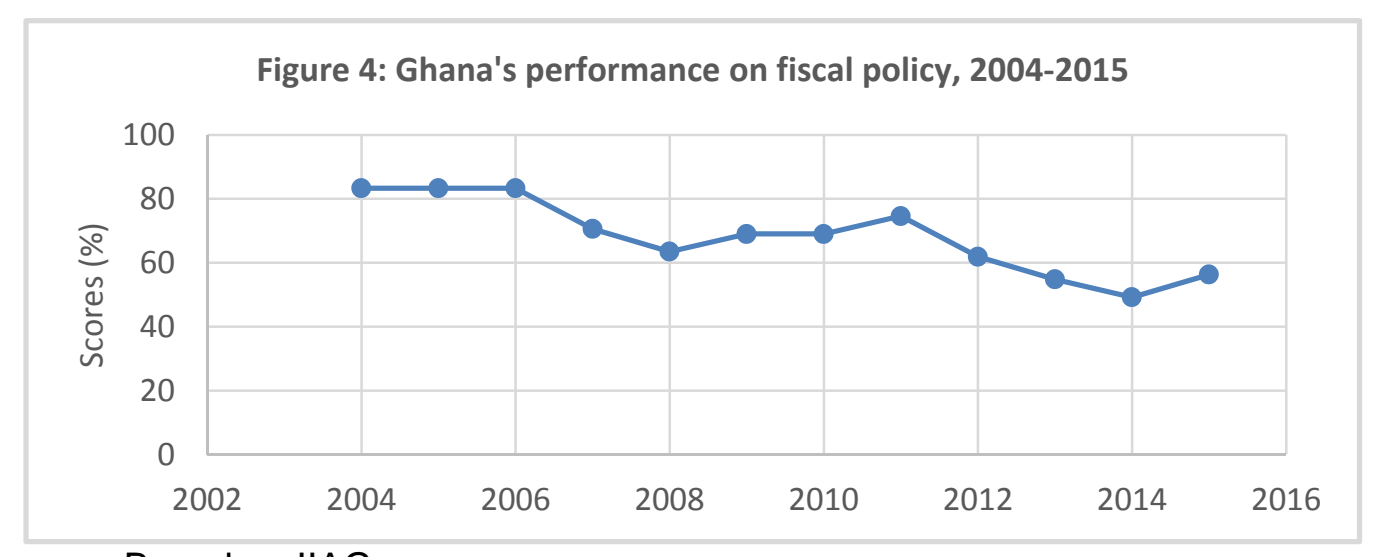

Source: Based on IIAG.

Table 2: Trends in selected PEFA scores for Ghana, 2006-2016

\begin{tabular}{|c|c|c|c|c|c|}
\hline PEFA & Indicator & 2006 & 2009 & 2012 & 2016 \\
\hline $\mathrm{PI}-5$ & Classification of the budget & B & C & C & C \\
\hline PI-6 & $\begin{array}{l}\text { Comprehensiveness of information included in } \\
\text { budget documentation }\end{array}$ & C & B & C & B \\
\hline $\mathrm{PI}-7$ & Extent of unreported government operations & A & A & $\mathrm{C}+$ & $\mathrm{D}$ \\
\hline $\mathrm{PI}-8$ & Transparency of inter-governmental fiscal relations & C & $\mathrm{D}+$ & $\mathrm{D}+$ & $\mathrm{D}+$ \\
\hline $\mathrm{PI}-10$ & Public access to key fiscal information & $B$ & A & B & B \\
\hline $\mathrm{PI}-11$ & $\begin{array}{l}\text { Orderliness and participation in the annual budget } \\
\text { process }\end{array}$ & $B$ & A & B & C \\
\hline $\mathrm{PI}-12$ & $\begin{array}{l}\text { Multi-year perspective in fiscal planning, } \\
\text { expenditure policy and budgeting }\end{array}$ & C & $\mathrm{C}+$ & $\mathrm{C}+$ & $B$ \\
\hline $\begin{array}{l}\text { P1- } \\
20\end{array}$ & Effectiveness of expenditure commitment controls & C & D & D & $\mathrm{C}+$ \\
\hline $\begin{array}{l}\text { P1- } \\
24\end{array}$ & Quality and timeliness of in-year budget reports & $\mathrm{C}+$ & C & C & $\mathrm{D}+$ \\
\hline
\end{tabular}

Nevertheless, relative to most public sector organisations in Ghana, the MoF is generally considered to be an effective organisation in the delivery of its core functions. At the start of the project, we conducted a survey with 27 experts in 
Ghana ${ }^{5}$ with the aim of assessing the general functionality or effectiveness of public sector organisations and identifying the most effective government ministries, departments and agencies for in-depth research. In reflection of the generally weak state capacity in Ghana, nearly half of our survey respondents (48 percent) reported that only a few government ministries are able to deliver their mandated functions effectively, whilst the majority generally fail to do so (see Appendix II). When respondents were asked to specify the ministries that they considered to be relatively effective in the performance of their mandated functions, the Finance Ministry topped the list, followed by the Ministry of Foreign Affairs (see Figure 5). While this finding is in line with recent studies that identify the MoF as a relatively effective public sector organisation in Ghana (see Owusu, 2006a, 2006b; McDonnell, 2017), a significant number of our survey respondents (19 percent) also identified the Ministry as among those public sector organisations whose performance has declined overtime.

\section{Figure 5: High-performing ministries in Ghana}

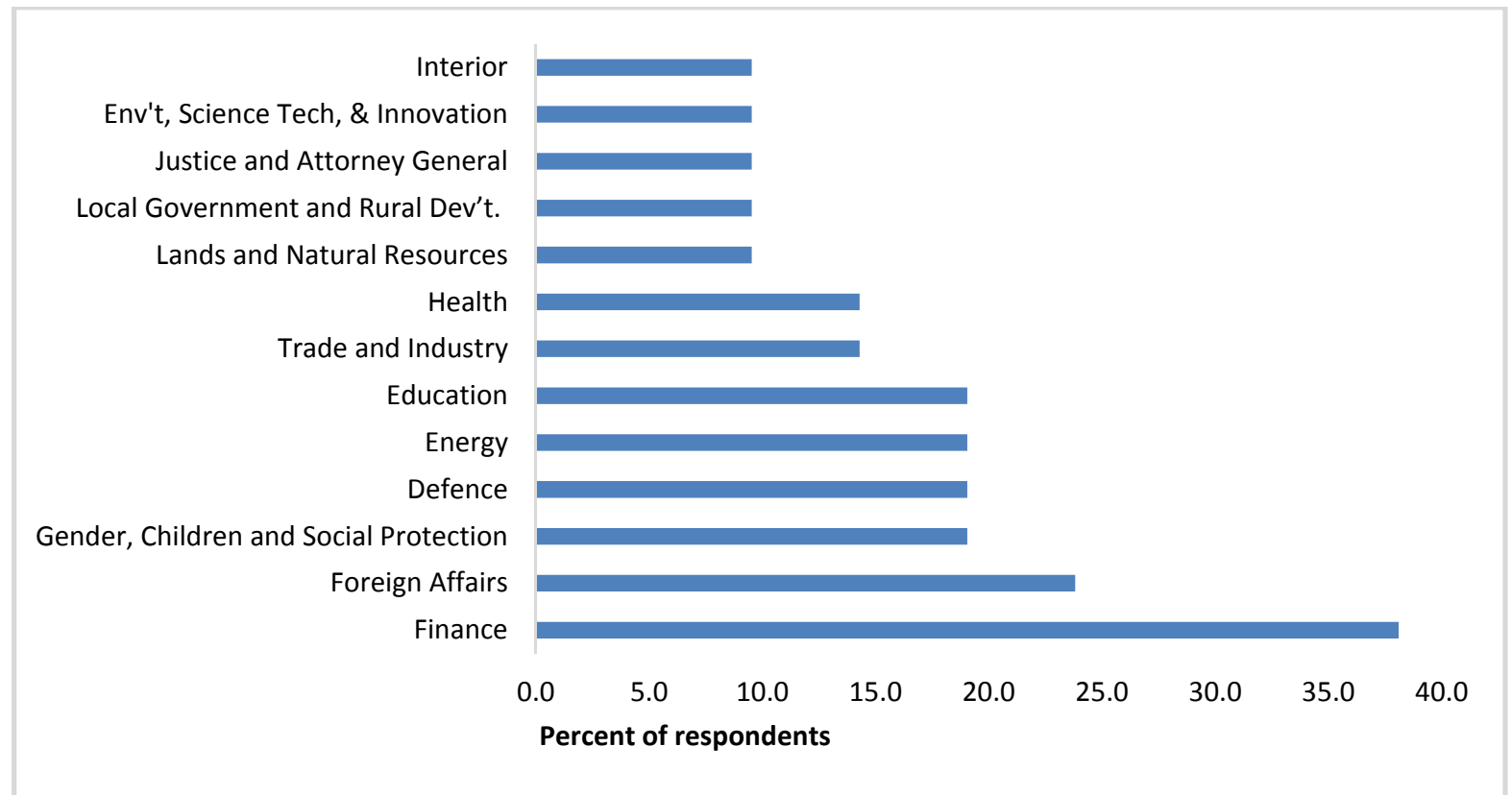

Source: Authors' survey results, January 2018.

\section{Political settlements theory and Ghana's PS}

Our argument about the performance of MoF is that the wider political settlement was coupled with internal organisational factors. Here we outline how we understand Ghana's political settlement in its broadest terms, look at where PoEs fit with this, and then outline the changing nature of Ghana's PS since independence and how this affected the MoF.

\footnotetext{
${ }^{5}$ These were drawn from academia, the public sector, civil society, donors and an independent consultant.
} 


\subsection{Political settlements and pockets of effectiveness}

Khan (2010) argues that although the imperatives of political stabilisation and the maintenance of power through clientelism are a common feature of all developing countries, the organisational structure of patron-client networks varies across and within countries over time, depending on the configuration of power in society. In brief, Khan argues that the highest levels of state capacity for development are likely to occur where the vulnerability of ruling elites is low, due to the absence of powerful factions that are horizontally excluded and the inclusion of strong lower-level factions within the ruling coalition. This level of regime security can encourage those in power to adopt a longer-term time horizon and reduces the transaction costs involved in implementing policies. Conversely, where there is a credible threat to the ruling coalition from powerful excluded groups, who may be able to wrest power through elections, and where lower-level factions are strong enough to make multiple demands on the centre, then the prospects for building long-term institutional capacity are diminished. These vertical and horizontal distributions of power give rise to four ideal types of ruling coalition that can be used to summarise the opportunities and constraints facing ruling elites. These are competitive clientelism (CC), vulnerable authoritarianism (VA), dominant party/leader (DL) and potential developmental coalition. Our analysis is structured using these broad categories, which we analyse collectively in the final section and summarise in Table 3.

Table 3: Drivers of Ghana's MoF's performance over time

\begin{tabular}{|c|c|c|c|c|}
\hline Time period & $\begin{array}{l}\text { Political } \\
\text { settlement type } \\
\text { and dynamics }\end{array}$ & $\begin{array}{l}\text { Ministerial } \\
\text { leadership }\end{array}$ & $\begin{array}{l}\text { Organisational } \\
\text { capacity and } \\
\text { culture }\end{array}$ & $\begin{array}{l}\text { Transnational } \\
\text { factors }\end{array}$ \\
\hline $1957-1966$ & $\begin{array}{l}\text { Competitive } \\
\text { clientelism } \\
\text { Concentration } \\
\text { of power in the } \\
\text { executive } \\
\text { Challenges from } \\
\text { powerful } \\
\text { excluded } \\
\text { factions }\end{array}$ & $\begin{array}{l}\text { High capacity } \\
\text { leadership } \\
\text { Technopol } \\
\text { who was } \\
\text { initially aligned } \\
\text { with president } \\
\text { Tension } \\
\text { between } \\
\text { 'political' } \\
\text { demands and } \\
\text { sound financial } \\
\text { management }\end{array}$ & $\begin{array}{l}\text { Good, but } \\
\text { dwindling } \\
\text { capacity, due to } \\
\text { political } \\
\text { interference } \\
\text { Strong support } \\
\text { by a competent } \\
\text { economic } \\
\text { advisor, Arthur } \\
\text { Lewis }\end{array}$ & $\begin{array}{l}\text { Good } \\
\text { commodity } \\
\text { prices } \\
\text { Good reserves } \\
\text { left behind by } \\
\text { colonial } \\
\text { administration }\end{array}$ \\
\hline 1966-1981 & $\begin{array}{l}\text { Vulnerable } \\
\text { authoritarianism } \\
\text { Rapid turnover } \\
\text { of leadership }\end{array}$ & $\begin{array}{l}\text { Ineffective, } \\
\text { due in part to } \\
\text { rapid turnovers }\end{array}$ & $\begin{array}{l}\text { Weak } \\
\text { bureaucratic } \\
\text { autonomy } \\
\text { Rapid policy } \\
\text { reversals }\end{array}$ & 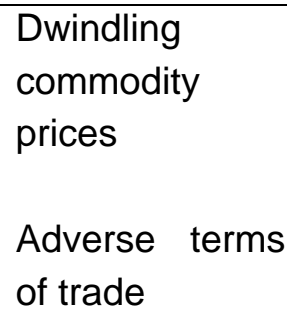 \\
\hline
\end{tabular}




\begin{tabular}{|c|c|c|c|c|}
\hline & $\begin{array}{l}\text { Lots of } \\
\text { horizontal and } \\
\text { vertical } \\
\text { challenges to } \\
\text { power }\end{array}$ & & & $\begin{array}{l}\text { Limited donor } \\
\text { support, with } \\
\text { creditor nations } \\
\text { refusing to } \\
\text { reschedule } \\
\text { repayment of } \\
\text { mounting } \\
\text { national debts }\end{array}$ \\
\hline 1982-1992 & $\begin{array}{l}\text { Dominant } \\
\text { Leader } \\
\text { Insulated } \\
\text { leadership }\end{array}$ & 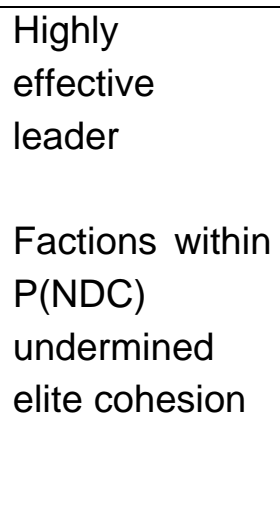 & $\begin{array}{l}\text { High capacity } \\
\text { but in small } \\
\text { technocratic } \\
\text { cell allied to } \\
\text { SAP } \\
\text { Perceived lack } \\
\text { of } \\
\text { accountability } \\
\text { to citizens }\end{array}$ & $\begin{array}{l}\text { Heavy } \\
\text { involvement of } \\
\text { donors through } \\
\text { SAPs } \\
\text { Management } \\
\text { systems } \\
\text { strengthened }\end{array}$ \\
\hline 1992-date & $\begin{array}{l}\text { Competitive } \\
\text { clientelism } \\
\text { Coalitions highly } \\
\text { vulnerable } \\
\text { Lower-level } \\
\text { factions } \\
\text { destabilise } \\
\text { authority }\end{array}$ & $\begin{array}{l}\text { HIPC - highly } \\
\text { effective } \\
\text { leader }\end{array}$ & $\begin{array}{l}\text { Reasonable } \\
\text { esprit de corps } \\
\text { Non-material } \\
\text { incentives } \\
\text { important }\end{array}$ & $\begin{array}{l}\text { Donors still } \\
\text { influential, both } \\
\text { through } \\
\text { technical and } \\
\text { financial } \\
\text { support, and } \\
\text { via } \\
\text { conditionalities }\end{array}$ \\
\hline
\end{tabular}

From the PS perspective, PoEs are more likely to emerge, be protected and to flourish within dominant than within competitive settlements, because the long-term vision to invest in building institutions and the capacity to do so is more likely to emerge within such contexts (Whitfield et al. 2015). In particular, immediate threats from outside and within the ruling coalition are lessened. Yet, competitive clientelism is the most common form of clientelism in developing countries (Khan, 2010), and has been the prevailing settlement type during much of Ghana's political history. This settlement type occurs when the ruling coalition faces strong excluded political factions and, internally, the ruling coalition is composed of strong lower-level factions and characterised by fragmentation among ruling elites. Under these circumstances, and because incumbent regimes are at risk of electoral losses, there is often 'little incentive for political leaders to invest in the long-term task of building bureaucratic capability' (Levy, 2014: 40). As a result, some observers note that 'Pockets of efficiency are difficult to create under Competitive Clientelism' (Whitfield et al., 2015: 106). Hickey et al. (2015) show that even where such agencies are created in 
countries characterised by competitive clientelism, as with Ghana's National Petroleum Corporation (GNPC), their endurance can easily be undermined by policy discontinuities engendered by interparty political rivalries.

\subsection{Ghana's political settlement dynamics: A periodisation}

In its post-colonial history, Ghana's political settlements dynamics have oscillated between competitive clientelism (1951-1966), vulnerable authoritarianism (19661981), a strong dominant leader type of settlement (1982-1992), and then back to competitive clientelism from 1993 up to the present (see Bebbington et al., 2018). Here, we give a brief overview of these changes and explore their implications for the performance of the MoF and macro-economic management more broadly. Figure 6 maps PS type against GDP growth as a way of inferring the linkages between PS and PoE performance, though we explore the detailed causality in subsequent sections.

Figure 6: GDP Trends under different political settlements in Ghana, 1961-2015

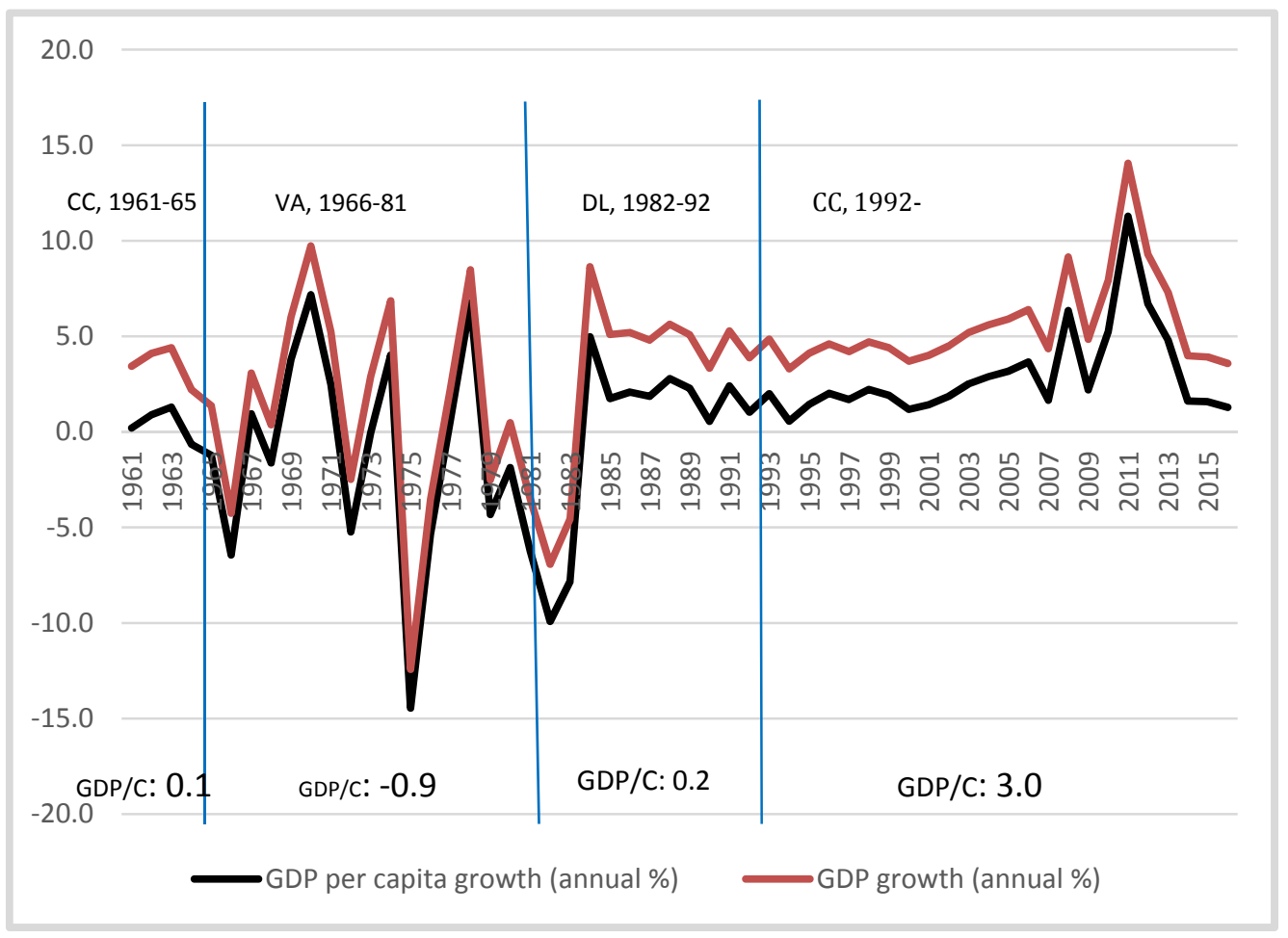

Source: Authors, based on World Development Indicators.

\subsubsection{Competitive clientelism in the early post-colonial period, 1947-1965}

The decolonisation struggle in Ghana played out in a context of extremely dispersed power among groups of elites, as well as significant political mobilisation and organisations across sections of society (Whitfield et al. 2015). The Nkrumah-led CPP won national elections organised in 1951, 1954 and 1956, and Nkrumah entered a power-sharing arrangement between the CPP and the colonial administration in 1954. The CPP ruling coalition remained highly vulnerable, due to the existence of strong excluded elite factions. To counter this vulnerability, the CPP 
resorted to the manipulation of economic policies and institutions, in order to serve the political objectives of consolidating the ruling coalition (Killick, 2010). This undermined attempts at development planning, as budgets and technocratic advice were routinely ignored. High-ranking CPP members in the government who voiced their opposition to these practices had strained relations with Nkrumah, who eventually forced them out of the ruling coalition, most notably Ghana's first finance minister, Komla Gbedemah (1954-1961). Gbedemah used fiscal policy in economic stabilisation just after independence. After worsening relations between him and Nkrumah over what Gbedemah perceived to be Nkrumah's financial indiscipline, Nkrumah gradually ousted Gbedemah, which removed a major restraint on Nkrumah's spending ambitions. To ensure the manipulation of fiscal policies for political gains, Nkrumah first took over responsibility for preparing the national budget himself, and then subsequently adopted a strategy of appointing more amenable finance ministers (Killick, 2010: 167). The growing vulnerability of the CPP incentivised Nkrumah to use economic policy-making processes as vehicles for patronage (Tignor, 2006). Nkrumah's chief economic adviser and eminent development economist, Arthur Lewis, advised against these practices to the point that 'the prime minister now rarely sought his advice' (Tignor, 2006: 172). Ultimately, Lewis resigned from his advisory position over concerns about Nkrumah's politically expedient spending.

The combined results were mounting budget deficits, negative growth rates (see Figure 6), and depleted foreign reserves, such that by the time of Nkrumah's overthrow in February 1966, the country's 'balance of payment was heavily in arrears' (Tignor, 2006: 191). For Rimmer (1990: 223), the origins of Ghana's economic decline under Nkrumah can best be understood within the context of the president's 'politically rational motives that inspired economically destructive policies'. This contributed to laying the basis of the high degree of vulnerability that characterised the six short-lived ruling coalitions that governed between 1966 to the end of the 1970s.

\subsubsection{Vulnerable authoritarianism, 1966-1981}

Following the military overthrow of Nkrumah, none of the seven short-lived military and civilian regimes that governed in the next decade-and-a-half was able to turn the economy around, as macroeconomic reforms were often undermined by political imperatives. Here, 'each (regime was) apparently too caught up in internal rivalries and personal ambition to give serious attention to the economy' (Berry, 2008: 39). Moreover, during much of this period, bureaucratic autonomy was curtailed, technocratic advice largely ignored, and there was limited political support for macroeconomic economic bureaucrats. This political instability resulted in macroeconomic chaos, as each successive regime reversed its predecessors' policies and attempted to chart a new economic course (Resnick, 2016). As Figure 6 shows, between 1974 and 1981, GDP dropped 15 percent, and production shrank in every sector of the economy (Tsikata, 2001). Although these outcomes cannot be attributed to a single factor, the relationship between macroeconomic bureaucrats 
and the executive - as with the Nkrumah era - had a central role to play. During much of this period, the economic technocracy in Ghana and the bureaucracy were characterised by 'betrayal, disappointments and lack of backbone by politicians. Macro-economic reforms had been designed and many hours of manpower expended only to see politicians balk at implementing them or gut them to appease public opinion and special interests' (Hutchful, 1997: 7).

\subsubsection{Dominant settlement under the PNDC, 1982-1992}

The severity of the twin economic and political crises created a window of opportunity for changing the political settlement into a dominant one between 1982 and 1992 under the leadership of Jerry Rawlings.

Unlike previous regimes, the PNDC was characterised by a large degree of cohesion among the higher-level factions of the ruling coalition. During this period, power became centralised around Rawlings, and the ruling coalition faced excluded political factions that had been weakened by a legitimacy crisis (Ninsin, 1991). For Rawlings, the established political elites were seen as responsible for the cyclical macroeconomic crisis, and therefore had very little legitimacy with which to challenge the PNDC (Chazan, 1991; Whitfield, 2018).

Four main factors explain the successful economic reforms during this period, three of which were directly underpinned by the dominant character of the political settlement at the time. These factors are the centralisation of power around Rawlings and his own personal commitment to reforms; a macroeconomic management team dominated by a technocratically competent set of political appointees; a significant degree of autonomy for the macroeconomic management team; and sustained donor support. With strong encouragement of, and financial support from, the World Bank and the International Monetary Fund (IMF), the Structural Adjustment Programmes (SAPs) of the 1980s were primarily led by the technical staff of the MoF. A wide range of reforms, including dramatic currency devaluation and strict limits on government spending, led to generous financial assistance from multilateral and bilateral donors (Lyon, 1997). Scholars concur in describing the impact of these reforms as 'dramatic' and 'salutary', especially with regards to restoring macroeconomic stability and stimulating economic growth. As Figure 6 shows, GDP grew at 6 to 7 percent annually from 1984 to 1988, the highest in sub-Saharan Africa at that time (Lyon, 1997: 1).

\subsubsection{Return to competitive clientelism: 1992 to date}

The return to competitive clientelism in late 1992 somewhat undermined the effectiveness of the Finance Ministry to implement and sustain economic reforms, and by extension undermined the state's macro-economic management capacity. The 1990s were characterised by a worsening macro-economic situation, as the government now 'began to openly manipulate economic policy to achieve political purposes as soon as Ghana's political opening began in earnest, in 1990' (Green, 1995: 578). With the return to competitive clientelism, MoF's capacity to ensure fiscal 
discipline was undermined by the growing vulnerability of the ruling coalition, resulting not only from the emergence of powerful excluded political factions, but also from growing fragmentations among political elites within the ruling coalition. There is evidence, here, therefore, to suggest that whether PoEs emerge and are sustained over time depends not only the extent to which ruling elites are vulnerable to powerful excluded elites, but also on the degree of elite cohesion within ruling coalitions. We explore this period in more detail.

\section{Competitive clientelism and macro-economic management}

The return to multiparty democracy saw the emergence of a de facto two-party system, in which the National Democratic Congress (NDC) and the New Patriotic Party (NPP) have dominated all elections. With each electoral cycle, the NDC and NPP have become increasingly competitive. Consequently, each ruling coalition is characterised by a high degree of vulnerability, providing strong incentives for ruling elites across both parties to place 'a premium on visible, quick-fix actions ... as against longer-term, slower-acting structural reforms' (Killick, 2008: 29; see also Abdulai and Hickey, 2016). As one donor official told us, the pursuit of short-term political survival strategies in the Fourth Republic has meant that 'from day one, politicians here are trying to figure out how they win the next election, not how to get growth going - that is a second order thing'. ${ }^{6}$ As such, Ghana's return to competitive clientelism was accompanied by substantial policy reversals, even as most members of the PNDC ruling coalition still remained at the helm of affairs. The Finance Ministry lost some of its capacity to implement and sustain economic reforms, and by extension undermined the state's macro-economic management capacity (see Green 1995; Hutchful, 1997, 2002; Tsikata, 2001; Whitfield, 2010; Killick, 2010; Resnick, 2016). Here we analyse the relationships between the current competitive clientelist PS and MoF's performance along four themes; elite cohesion, politicisation of appointments, the political business cycle, and role of donors.

\subsection{Elite cohesion}

With the return to competitive clientelism, the strength of Rawlings's commitment to the tight monetary and fiscal policies that underpinned the success of the SAPs was weakened by concerns about how Ghanaians were reacting to reforms and, more importantly, by his desire to win popular votes (Jeong, 1998). Hutchful (2002) argued that part of this challenge came from managing the changing requirements of power and the more complex mobilisational structures that now underpinned the regime. For example, despite the initial continuities in the composition of the ruling coalition, power drifted increasingly from the technopols of the PNDC period to the party brokers of the new NDC. This corresponded to a shift in the priorities of the ruling coalition from a single-minded focus on the economy to a broader concern with retaining incumbency (Hutchful, 2002: 221).

\footnotetext{
${ }^{6}$ Donor official, 18 November 2017.
} 
Under competitive clientelism, the Finance Ministry's commitments to expenditure ceilings were undermined by a number of factors, including growing opposition to its policies, not only by excluded political factions, but also from among other powerful elites within the ruling coalition. One example was the Ministry's dispute with the state-owned oil company, the GNPC, whose borrowing put the government's money supply severely off balance. Botchwey's efforts to control GNPC's budget generated a dispute with its chief executive, Tsatsu Tsikata, himself a key member of the PNDC, and a close personal ally of Jerry Rawlings. Partly as a result of this, relations between Botchwey and Rawlings deteriorated (Green, 1995: 583). In August 1995, Botchwey resigned from his position, primarily in protest against his inability to restrain the excessive budgetary demands of the public sector, notably the uncontrolled spending by the parastatal GNPC (Jeong, 1998; Hutchful, 2002), as well as his resistance to 'a plan for a spending splurge to win the 1996 elections' (Africa Confidential, 2016). One account suggests that Botchwey's departure was no longer worrisome to Rawlings because he was now viewed to be 'too tough and politically insensitive; intent on the financial bottom line, he was inattentive to the political repercussions of scrupulous adjustment' (Green, 1995: 583). Immediately after his resignation, a purge of the Ministry of Finance swept away much of the technical team that had underpinned the ERP (Hutchful, 1997: 39). By 1997, the entire macroeconomic management team was gone (Whitfield, 2010). These observations echo the political drivers of Ghana's macroeconomic crisis that resulted from the exit of Nkrumah's economic advisor (Arthur Lewis) and finance minister (Komla Gbedemah) during the 1960s.

The internal opposition faced by both Gbedemah and Botchwey was more recently repeated during the leadership of Seth Terkper, finance minister from January 2013 to December 2016. Under Terkper's leadership, the MoF undertook several progressive but politically difficult reforms, including the removal of fuel and energy subsidies, that contributed to mounting debts; the establishment of the Ghana Integrated Financial Management Information Systems (GIFMIS); as well as the passage of a new Public Financial Management Act in 2016. The GIFMIS aims to provide the government with an ICT-based platform for improving public financial management. Using the GIFMIS system meant that only duly authorised purchase orders would be recognised as valid commitments of government and therefore payable from budgetary allocations (see Gbana, 2014). The persistent problem of election campaigns leading to excessive budget deficits, discussed below, also prompted the Ministry to undertake reforms that culminated in the passage of a new Public Financial Management Act (2016), Act 921. While the impacts of these efforts are yet to be felt significantly on the ground, preliminary assessments in the most recent Ghana PEFA report point to some positive outcomes. For example, the GIFMIS is noted to 'have succeeded in strengthening controls' (Government of Ghana, 2018: 161) and there has also been 'significant improvement ... in cash and treasury management since 2016' (ibid: 33). During fieldwork, we repeatedly heard stories of how the new sanctions regime embedded in the 2016 PFM Act are already putting public officials on their toes: 'In the PFM Act are sanctions. So, if ... you don't 
do the right thing you will be jailed. So, people are very careful now because it has been put into law'. ${ }^{7}$

Like Botchwey, Terkper was more of a 'technopol' than a technocrat or a pure politician, with the Business and Financial Times describing him as one of Ghana's finance ministers 'who separated economics from politics'. ${ }^{8}$ Several senior bureaucrats told us that Terkper's leadership style was different from that of most past ministers, because he viewed things mainly from the technocratic, rather than the political, point of view and took decisions irrespective of their political implications for the governing party. For one respondent, his background as an ex-IMF staffer shaped the kind of reforms that were implemented during his time as finance minister. For example, crediting the passage of the PFM law primarily to his efforts and commitments to 'sanitising' the existing system, one respondent noted:

'At the time we mooted the law, you know the then minister was more of a technician than a politician. I mean Honorable Seth Terkper. You know he was a PFM practitioner, he was into taxation and had worked with the IMF or so. And, so, with that background, he also saw the need to put in the systems. So, if you look at the policy initiatives in our budget at that time, he was looking at putting in the systems to control expenditure .... If you pick a copy of our budget and look at all the policy initiatives in his time, they were all policy initiatives to sanitise the system. And, so, the law was a climax of it. ${ }^{9}$

Additionally, some senior bureaucrats highlighted Seth Terkper's consistent resistance to political pressures to release funds for unbudgeted spending. Highlighting how political pressures sometimes impact their work, one civil servant singled out Terkper as an exception:

'But we have had some ministers that did not take that political pressure ... for example, Hon. Seth Terkper wasn't allowing the political pressures to work on him. He was a technocrat before. So, he wasn't taking political decisions. So, when they come [to make request for unbudgeted spending] he will say no, there is no money'. ${ }^{10}$

Barely two years into his appointment, political pressures began to mount on President Mahama to get Terkper removed from office. Importantly, such pressures came not from opposition party politicians, but mainly from party foot soldiers and leading members of the ruling NDC, who were concerned about the potential adverse implications of the minister's fiscal discipline measures for the retention of their party in power; which parallels Nkrumah's antipathy towards Gbedemah. The Al-Hajj, a

\footnotetext{
${ }^{7}$ MoF official, 31 May 2018.

${ }^{8} 20$ December 2016 'The end of Terkpernomics ... What legacy does he leave behind?' Available at: http://ghanapoliticsonline.com/end-terkpernomics-legacy-leave-behind/ (accessed 3 June 2019)

${ }^{9}$ MoF official, 8 June 2018.

${ }^{10}$ MoF official, 31 May 2018.
} 
pro-NDC newspaper, complained of Terkper's 'unrepentant desire to force dangerous economic prescriptions' on the citizenry without thinking about the 'political ramifications' of such policies. ${ }^{11}$ At the same time, the deputy general secretary of the ruling NDC cautioned that they 'will not allow Terkper to walk NDC into opposition'. ${ }^{12}$ Such concerns were also publicly raised by some leading NDC members, including ministers of states, ${ }^{13}$ a problem that was to be acknowledged by President Mahama himself. In a conversation with the managing director of Barclays Bank Ghana at the seat of the presidency, several media houses (including the stateowned Daily Graphic) reported the president to have stated: 'I mean several times they've interceded with me to sack Seth because he's hurting the politics. He doesn't understand the politics'. ${ }^{14}$

These observations are not surprising because, as Roll (2014a) has argued, agitations for the removal of PoE chief executives are common because such 'organisations often interfere in or come into conflict with activities in which other politicians or other members of the elite have specific interests' (p.212). To this extent, Roll (ibid) argues that political protection from a powerful politician, often the head of state, is an effective safeguard against such attacks and indeed 'indispensable' for the persistence of PoEs (Roll, 2014a: 212). Terkper's ability to undertake such politically difficult decisions was buttressed by the availability of political protection at the highest level of government. Terkper could not have imposed such policies without the consent of cabinet and the government's economic management team headed by the vice president - a point publicly acknowledged by the finance minister himself. ${ }^{15}$ More importantly, President Mahama not only publicly

\footnotetext{
${ }^{11}$ See The Al-Hajj, 23 January 2014, 'Sinking economies and sleaze: Can Terkper save Mahama?' Available at: https://www.ghanaweb.com/GhanaHomePage/NewsArchive/SinkingEconomies-Sleaze-Can-Terkper-save-Mahama-298593 (accessed 30 May 2019).

${ }^{12}$ See the Pulse News, 2 June 2016, 'We will not allow Terkper to walk NDC into opposition Koku Anyidoho'. Available at: https://www.pulse.com.gh/news/politics/ghana-tax-law-we-willnot-allow-terkper-to-walk-ndc-into-opposition-koku-anyidoho-id5106041.html (accessed 30 May 2019).

${ }^{13}$ See Daily Guide, 3 May 2014. 'Sack Seth Terkper; NDC gurus pressure Mahama'. Available at: https://www.modernghana.com/news/538725/sack-seth-terkper-ndc-guruspressure-mahama.html (accessed 13 June 2019).

${ }^{14}$ See Citifmonline, 16 January 2014, 'I'm under pressure to fire Seth Terkper - Mahama'. Available at: https://www.graphic.com.gh/news/politics/i-m-under-pressure-to-fire-sethterkper-mahama.html (accessed 30 May 2019). See also see also Radion XYZ News, 16 January 2014, 'President Mahama says he is being forced to SACK finance minister Seth Terkper'. Available at: https://www.ghanacelebrities.com/2014/01/16/president-mahama-saysforced-sack-finance-minister-seth-terkper/ (accessed 30 May 2019);_Myjoyonline, 1 April 2014, 'Mahama Ayariga betrays Seth Terkper'. Available at: https://www.newsghana.com.gh/mahama-ayariga-betrays-seth-terkper/ (accessed 30 May 2019);_Peacefmonline, 31 March 2014, 'Terkper gives us headache - Ayariga'. Available at: http://www.peacefmonline.com/pages/politics/politics/201403/194746.php (accessed 30 May 2019).

${ }^{15}$ See myjoyonline news, 26 September 2017, 'I am not the cause of NDC 2016 defeat Seth Terkper'. Available at: https://www.myioyonline.com/business/2017/september-26th/iam-not-the-cause-of-ndc-2016-defeat-seth-terkper.php (accessed 30 May 2019).
} 
agreed with his finance minister, but also provided him with the political cover to carry on with his various austerity measures. ${ }^{16}$

\subsection{The politicisation of bureaucratic appointments}

Observers have long identified political patronage as an important impediment to developmental performance in Africa, especially in contexts where 'patronage systems result in ... firing practices that place and displace people for reasons of party affiliation' (Grindle, 1997: 487). More recent evidence suggests, however, that patronage systems do 'not necessarily have negative consequences for the overall management of organizations' (Grindle, 2012: 23) and has, in some cases, even contributed to 'the construction of competence in government' (ibid, p.7). Grindle (2012: 261) argues that because patronage systems tend to be controlled by political executives in contemporary societies, 'ministers and other high-level officials have the capacity to use their appointment power to attract highly qualified staffs to carry out specific policy initiatives' in ways that improve organisational performance.

Since the return to multiparty democratic elections, the MoF has had one of the most stable political leaderships in Ghana, as most presidents have allowed their finance ministers relatively long tenures to manage the economy. Between 1993 and 2017, there have been only eight finance ministers, compared to 15 for health and 14 for education. However, this stability is accompanied by significant disruptions among bureaucrats, as chief directors and other people in management positions are often replaced with new appointees, particularly during political transitions. For instance, 'when the government changed after the 2000 election, the incoming NPP government introduced new staff throughout the hierarchy of the Ministry of Finance, which brought major disruptions' (Lawson, 2012: 54). By January 2003, the newly appointed finance minister, Osafo Maafo, had reshuffled at least eight senior officials out of the Ministry. ${ }^{17}$ In January 2005, Osafo Maafo was reshuffled to head the Education Ministry, and took many technocratic officers from the MoF along (Fyson, 2009: 332).

One senior civil servant narrated why and how such problems sometimes occur:

'What I see happening is that when a new minister comes, he will say that I have to work with a chief director I can trust ... so sometimes you have one chief director moved, but you don't have a new one come in because the minister involved is probably not getting the "right"chief director he wants to work with. ${ }^{18}$

\footnotetext{
${ }^{16}$ See Citifmonline, 16 January2014 , 'I'm under pressure to fire Seth Terkper - Mahama'. Available at: https://www.graphic.com.gh/news/politics/i-m-under-pressure-to-fire-sethterkper-mahama.html (accessed 30 May 2019). See also see also Radion XYZ News, 16 January 2014, 'President Mahama says he is being forced to SACK Finance Minister Seth Terkper' Available at: https://www.ghanacelebrities.com/2014/01/16/president-mahama-saysforced-sack-finance-minister-seth-terkper/ (accessed 30 May 2019).

${ }^{17}$ Daily Graphic 31 January 2003. 'Shake-up at Finance Ministry'.

${ }^{18}$ Divisional director, 16 May 2018.
} 
This implies that such reshuffles are not necessarily directed at dealing with incompetence, but are primarily driven by concerns around 'personal loyalty and perceived party affiliation' ${ }^{19}$ and therefore as one way of building patronage for governments (Ayee, 2008: 30). As a result, such redeployments occur not only during regime changes between political parties, but also within parties, as many newly appointed ministers request to work with civil servants 'they can trust'. ${ }^{20}$

While much current scholarship on Ghana has highlighted the adverse implications of this practice, as evidenced in the above quotes, our interpretation here is somewhat different. As Grindle (2012) has argued, whether patronage leads to incompetence and poor organisational performance depends on a variety of factors, including 'the agendas of those who controlled the distribution of patronage' (p.7). In the specific context of the MoF, one underlying motive for the personalisation of the bureaucracy by politicians is to engender trust and ensure the loyalty of bureaucrats working under them in a context where the line between government and party has become increasingly blurred. Ayee (2013) provides several cases where high profile public administrators openly engaged in partisan politics, including one sitting chief director of the Finance Ministry who was approved to contest the 2,000 parliamentary elections on the ticket of the NDC. Indeed, some key informants told us that politicians are in many cases right to reject working with certain bureaucrats who have become so politically compromised that they are unlikely to gain the trust of new political regimes.

These regular changes in personnel that accompany the frequent electoral turnovers have resulted in the delayed implementation of important PFM reforms (Fyson, 2009; Lawson, 2012; Betley et al., 2012), as new political and bureaucratic appointees are sometimes unwilling to pursue their predecessors' legacies for political reasons. This problem reflects the broader incentives generated by competitive clientelism in Ghana, whereby 'the imperative of winning elections has sometimes resulted in a layering of new priorities onto existing development strategies for the party in office to show its imprint' (Resnick, 2016: 23). Moreover, during political transitions, senior bureaucrats who were seen working closely with political heads from the previous regime are viewed with suspicion, with the result that some high-performing bureaucrats are either reshuffled out of the Ministry or sidelined in their dealings with the new political leadership. Given the long period of time it often takes for the new political leadership to begin to get along with these perceived politically disloyal bureaucrats, every political transition is often characterised by a polarised working environment within the Ministry.

Working with such 'compromised' bureaucrats is likely to hurt rather than help the performance of organisations, not least because this is likely to constrain bureaucrats in the exercise of discretion. Evidence suggests that technocratic expertise can have

\footnotetext{
${ }^{19}$ Interview, MoF divisional director, 16 May 2018; see also The Insight, 9 April 2013.

${ }^{20}$ MoF divisional director, 16 May 2018.
} 
the greatest impact on organisational performance when leaders possess enough trust from political elites to gain opportunities for the exercise of various forms of discretion that may allow them to push unconventional organisational practices (see McDonnell, 2017: 498). Roll's (2014a) notion of 'effective political management' as a necessary condition for establishing and maintaining PoEs comes into play here. Importantly, political elites are likely to tolerate greater organisational discretion when they have interpersonal ties with organisational leaders, as was the case of the GNPC under Tsatsu Tsikata during the 1980s-1990s (Hickey et al., 2015; Opoku, 2010). As McDonnell (2017: 498) aptly puts it: 'significant discretion is only tolerated where loyalty is assured'.

\subsection{Political business cycles}

The third major feature is the persistence and worsening trend of political business cycles, as governments engage in excessive overspending in order to maintain their ruling coalitions and avoid the cost of losing power in a competitive clientelist political setting. Mosley and Chiripanhura (2016) have recently demonstrated a relationship between the degree of electoral competition and the extent of political business cycles (PBCs) among a number of African countries. They argue that 'where there is greater political competition, incumbent parties are more inclined to increase the deficit level prior to an election' (p.919), and that the PBC occurs relatively infrequently in 'dominant-party systems' where a pre-election stimulus confers little political advantage on incumbent regimes (ibid, p.917).

Since the return to multiparty democracy in 1992, Ghana's PBC has worsened, reflecting greater political pressures on economic technocrats during election years. With the notable exception of 2004, each election year has been characterised by excessive spending, leading to higher fiscal deficits, and the next two to three years are often used to bring back the deficit to its initial level (World Bank, 2011: 1; Asiamah et al., 2014: 1, 22; Osei and Telli, 2017: 73). Incentives to overspend in election years are driven by the perceived cost of losing power in a competitive clientelist political setting. Figure 7 shows that in the last five election years, between 2000 and 2016, the average budget deficit as a percentage of GDP was 9.5 percent, compared to 6.5 percent for non-election years. For example, on the eve of the 1992 elections, the government announced a salary increase of about 70-80 percent for many public sector workers - a decision which alone raised the wage bill to 8 percent of GDP. Huge public spending before the elections produced a budget deficit that was financed by the banking system, and expansion of the money supply resulted in higher inflation (Jeong, 1998: 223-224; IMF, 1998).

Similarly, as the 1996 elections approached, additional fiscal 'slippages' were apparent as the NDC increased capital spending to maintain the support it had gained from the previous elections, while responding with salary increases after a set of successive strikes by doctors, nurses, workers of the Ghana Cocoa Board, railway employees, and civil servants (Leite et al., 2000). In general, the capacity of MoF bureaucrats in curbing this problem remains limited, not because of insufficient 


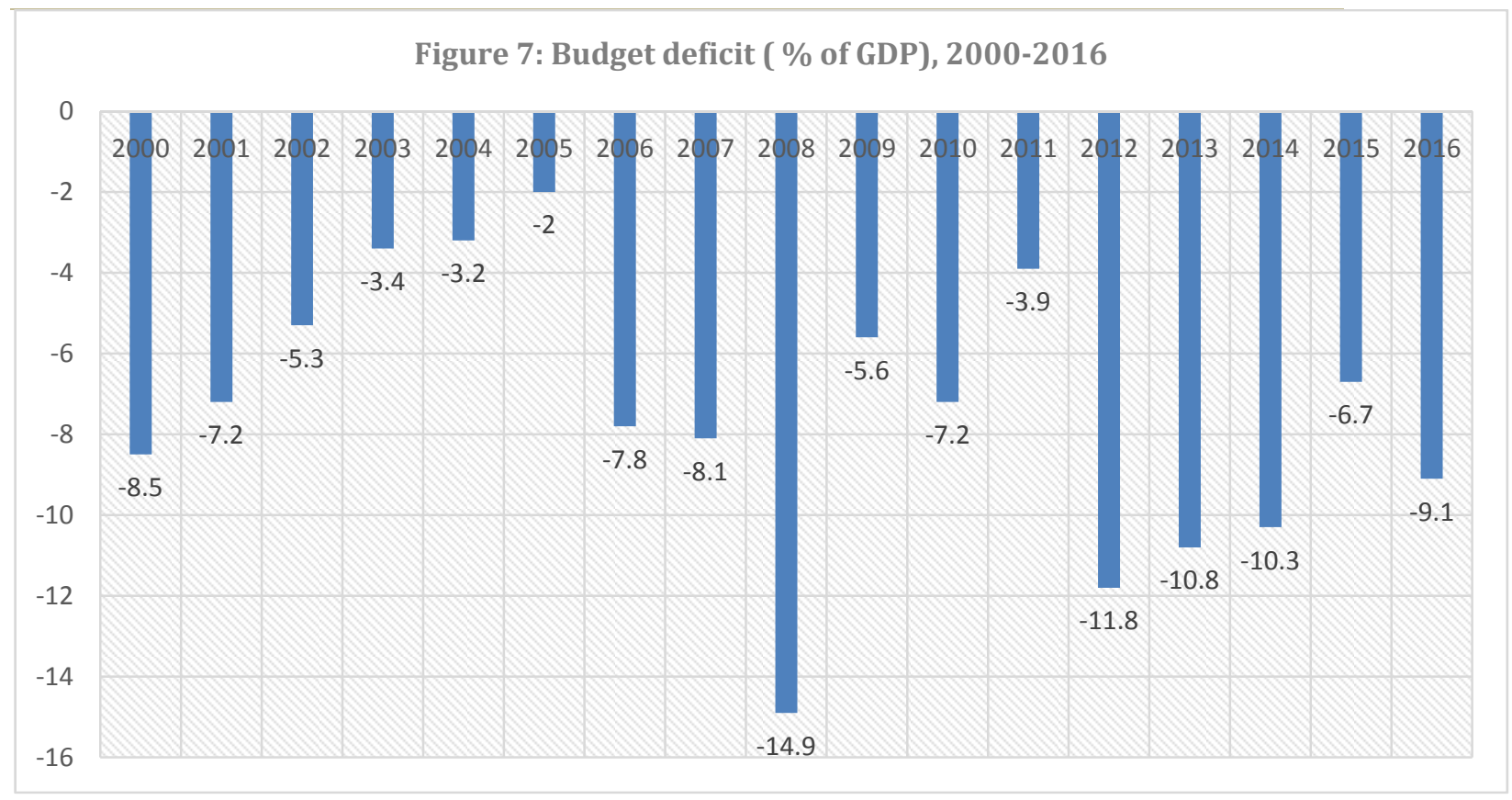

Source: Budget Unit, MoF, Accra.

technocratic expertise within the Ministry, but because of politicians' limited commitment to heeding technocratic advice in the context of mounting electoral pressures. Our key informants explained the problem of political business cycles primarily as a product of the varied extent to which politicians heed technocratic advice during election and non-election years: 'in the non-election years, there are nopolitical incentives .... to ignore technocrats, so technocratic decisions are followed. But where the political stakes are high, technocratic advice becomes like a poison'. ${ }^{21}$

One explanation for the relatively high level of fiscal discipline in 2004 (an election year) relates to effective leadership in the person of Osafo Maafo, the first finance minister during the Kufuor administration (2001-2008). As minister, Osafo Maafo's achievements were recognised internationally in 2001, when he was adjudged the best finance minister of the year in Africa by the Banker Magazine. Along with the finance minister of Canada, he was also named Finance Minister of the Year in November 2001 by the World Economic Forum in Davos. Osafo Maafo was particularly credited for his negotiation capacity with donors and his stringent leadership style, particularly with regards to expenditure controls. In presenting his 2004 budget statement, Osafo Maafo was emphatic that:

' $[\mathrm{t}] \mathrm{he}$ exigencies of an election year will not divert us from the pursuit of rational economic policies ..., I am glad to be able to give assurance ... that in this election year, we will continue to pursue the prudent economic policies that have enabled us attain our present healthy economic status. We will not

${ }^{21}$ MoF's head of unit, 16 May 2018. 
allow any slippages in responsible economic management to derail us from our chartered course' (Republic of Ghana, 2003: 5-6).

Following his introduction of new cash and commitment control systems, expenditure increases in 2003 were well below the rate of increases in tax collection (ibid., p.6) and expenditures were kept within budget ceilings (ibid., p17). Figure 8 shows that even the Office of Government Machinery (OGM), of which the presidency is part, rarely spent more than its budgeted sum during this period: throughout the three-year period from 2003 to 2005, the OGM consistently spent slightly less than its budgetary allocation, underscoring the relative fiscal discipline during this period. This translated into improvements in several macroeconomic indicators: the overall budget deficit was reduced from -8.5 percent in 2000 to just -2 percent by 2005 (see Figure 8), while inflation was reduced from over 40 percent when the NPP came into power to 11.8 percent by 2005 (Debrah, 2009: 103).

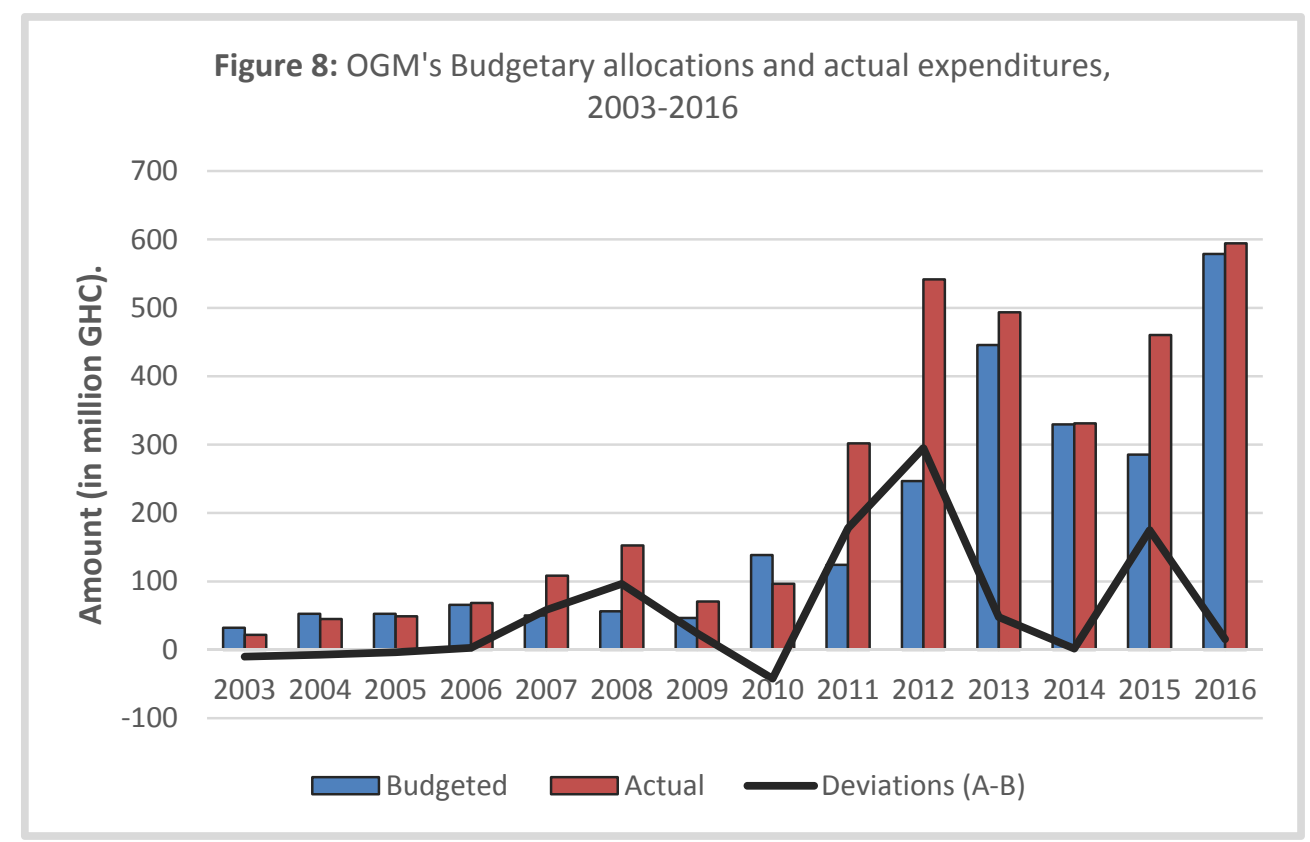

Source: Authors, based on data extracted from the annual budget statements and annual reports of the Auditor-General Department, various years.

However, such a stringent leadership was to partly cost him his job, as it did Komla Gbedemah in the 1960s and Kwesi Botchwey in the mid-1990s. Immediately after the December 2004 elections, a new ministerial reshuffle saw Osafo Marfo replaced, to the surprise of many, including opposition party members. For Ayee (2008: 32), this particular reshuffle contributed to 'weakening the administrative capacity of the Kufuor government to delivery'. Moses Asaga, then minority spokesperson on finance, described Osafo Maafo's replacement as his 'biggest surprise', stating further that 'the change was not necessary. He is an experienced minister, a very good negotiator and has done quite well as minister for finance and economic 
planning and should have continued'. ${ }^{22}$ Lauding Osafo Maafo's achievements on the macroeconomic front, Asaga expressed shock as to why President Kufuor saw wisdom in replacing someone who, 'for the first time, ... was able to resolve the cyclical problem of loose fiscal and monetary policies, characteristic of election years'. ${ }^{23}$ Some accounts suggest that the removal of Osafo Maafo as minister of finance was primarily informed by his refusal to pursue lax fiscal policies ahead of the 2004 elections in ways that denied the ruling NPP the needed campaign funds. For example, Moses Asaga expressed scepticism about the potential of Kwadwo BaahWiredu (who replaced Osafo Maafo) to curb inflation, given that 'one of the main reasons for the removal of Osafo-Maafo from the ministry, was the feeling within his party that he had denied them campaign funds'. ${ }^{24}$

\subsection{Donors}

A fuller understanding of the MoF's performance also requires considering the important role played by donors in the form of financial and technical assistance, combined with formal aid conditionalities as well as less formal political influence. In the 1980s, as part of the SAPs, bilateral and multilateral donors played an important role in enhancing the institutional capacity of the Finance Ministry, especially through implementation of the Structural Adjustment Institutional Support Programme (SAIS, 1987-1993). With an IDA (International Development Association) credit of US $\$ 10.8$ million, the SAIS focused on the most critical needs of public sector management, giving particular priority to improving the effectiveness of economic management institutions. Among others, the SAIS sought to improve economic policy management by strengthening economic policy analysis, formulation and co-ordination in the then Ministry of Finance and Economic Planning (MFEP), through measures such as:

i. Establishment of an Economic Policy Unit (EPU $)^{1}$ in the MFEP as the nucleus for rebuilding the Ministry's capacity to analyse economic policy issues, review economic trends and performance, advise the government on appropriate economic policies, as well as provide support and advice to the heads of MFEP's five functional divisions; and

ii. Strengthening the public investment, planning, budgeting and expenditure control, revenue mobilisation, and debt management and aid coordination capabilities of the MFEP by restructuring the relevant divisions of the Ministry ${ }^{1}$ through staff training, computerisation and infrastructure support (World Bank 1993: 2).

Under the SAIS, over $\$ 1.1$ million was allocated to training for staff, both locally and abroad, with much of these resources earmarked for MFEP. The Harvard Institute of International Development's programme on Investment Analysis and that on Budget and Finance were attended by some staff of the Budget Division, while staff

\footnotetext{
${ }^{22}$ Public Agenda, 17 January 2005, 'Asaga shocked by Osafo Maafo's removal'. Available at: https://www.ghanaweb.com/GhanaHomePage/NewsArchive/Asaga-Shocked-By-OsafoMaafo-s-Removal-73678 (accessed 3 June 2019).

${ }^{23}$ Ibid.

${ }^{24}$ Ibid.
} 
responsible for implementing the Public Investment Programme also attended a course on Project Planning and Appraisal at the Institute. To achieve the objective of improving and rationalising debt management, personnel of the debt management unit were provided with training in the UK in the use of the Commonwealth Secretariat computerised debt record management system. An evaluation of the SAIS noted 'useful improvements in capacity ... in respect of public investment programming, external debt management, tax administration, and civil service reforms...' (World Bank, 1993: 10). Overall, training appears to have contributed to improved management capacity of various agencies, especially the budget division of the MFEP (ibid, p.7).

Anaman (2016) and Osei et al. (2013) explain the relatively high level of fiscal discipline in the early 2000s and the low level of fiscal deficit in the 2004 election year in terms of donor conditionalities, particularly the strict compliance to the HIPC (Highly Indebted Poor Country) initiative conditions set for fiscal management. This argument is supported by the fact that after reaching HIPC completion point in 2004, and a completion of the HIPC process in 2006, the country's fiscal position began to worsen again, so that the fiscal deficit in 2008 was more than twice the 2004 figure.

Some observers explain the political protection of finance minister Terkper in terms of President Mahama's concerns about Ghana's international reputation and the likely fall-out of donors with government should the minister be sacked simply on the grounds of being 'too strict' for the liking of key party insiders. This perspective holds that if the president yielded to such political pressures by changing the finance minister, it would convey the signal that he was not ready to correct the fiscal indiscipline of the NDC that had started mainly from around the 2012 elections. If the president had heeded the political pressures to sack his finance minister, it is likely that donors would have slowed down (or possibly withheld) disbursements of their pledges of budgetary support and development assistance. This point must be understood within the context of the important role played by donors in the ongoing macroeconomic reforms at the time. For example, the GIFMIS is being implemented with financial and technical support from the World Bank, DFID, the European Union, and DANIDA.

Highlighting the role of donor conditionalities in the relative macroeconomic stability achieved during 2015-2016 period, one study notes that 'most' development partners withdrew their budget support in 2013-2014, insisting that they would not resume budget support until important macro-actions were undertaken by government. Budget support only resumed in 2015 after a stabilisation of the macroeconomic environment that followed implementation of the government's 'home-grown' stabilisation programme with support from the African Development Bank (EU Development and Cooperation, 2017a). Thus, whereas donor disbursements resumed at a high level in 2015, these disbursements were directly 'linked to tranches that were withheld in the years 2013 and 2014' (EU Development and Cooperation, 2017b: 15). It is important to add, however, that the significant offbudget expenditures that took place towards the 2012 elections, and which 
significantly undermined macroeconomic stability, occurred amidst an IMF Extended Credit Facility that had structural benchmarks (including quantitative targets on the nominal budget deficit) aimed at reducing budget deviations and improving fiscal reporting (ibid., p.68). The important question, therefore, is why donor support and its associated conditionalities failed to curb the macroeconomic challenges at the time, and what eventually led to government's request for an IMF bailout in 2014?

Here the political context and the interests of the ruling coalition are important. President Mills died while in office in July 2012, and Vice President John Mahama took over the presidency. Shortly thereafter, Mahama became the NDC's presidential candidate towards the December 2012 elections, which the party knew was bound to be highly competitive, given that his main opponent (the NPP's presidential candidate, Nana Akufo Addo), had lost the previous elections in 2008 by a very slim margin of less than 0.5 percent of the total votes cast. Mahama eventually won the election, but at the expense of an unprecedented pre-election boom. The political imperative of winning the 2012 elections therefore took precedence over elite commitment to PFM reforms. This underscores the limits of external actors in pushing for reforms that appear to be at variance with the interest of domestic political elites. ${ }^{25}$ As Johnson (2015:784) also concluded, 'donor requirements can encourage African leaders to create pockets of effectiveness when donor incentives complement domestic political calculations'.

\section{Understanding MoF's relative effectiveness: The role of organisational factors}

Based mainly on the primary data gathered for this report, this section discusses the ways in which the wider political settlement and the internal organisational factors are co-constituted and how these interactions have facilitated the Ministry's emergence and endurance as a relatively effective public sector organisation in Ghana. In line with existing literature on PoEs (see Grindle 1997; Leonard, 2010), these factors include organisational culture, performance-oriented incentives, and highly qualified personnel facilitated by various human resource management practices.

\subsection{Organisational culture and a high sense of mission}

The literature on PoEs suggests that a strong sense of organisational mission and public service is an important determinant of where PoEs emerge and are sustained (Leonard, 2010; Roll, 2014a). Grindle (1997) goes further to argue that, even in contexts of severe resource shortages and poor working conditions, a widely held sense of purpose within an organisation - what she termed 'organisational mystique' - can result in staff commitment to the goals of the organisation and in eliciting hard and consistent effort from them, leading to higher levels of productivity.

\footnotetext{
${ }^{25}$ For similar observations within the specific Ghanaian context, see Abdulai and Hulme (2015).
} 
The MoF had a strong sense of organisational identity. Civil servants believed that the culture of work in the Ministry sets it apart from other bureaucracies, especially with regards to how much time staff spend on the job. Most staff report to work quite early, sometimes well before the official reporting time of 8am. Civil servants bragged of their long hours of work and intense work expectations. One former official of the Ministry stated: 'In most of the units, people don't come to work anyhow. I can vouch for Ministry of Finance ... on average, I can say that 80-85 percent of staff come to work early'. ${ }^{26}$ These observations are in sharp contrast to the generally poor organisational culture in Ghana's public sector, where 'Civil servants trickle into offices between 9 and 11 a.m.' and where many staff leave their offices 'before formal closing time' (McDonnell, 2017: 484, 487). Within the budget division, there is at least one schedule officer for each ministry who is responsible for processing requests from their respective Ministries, Departments and Agencies. For one key informant, staff of the budget division could be equated to bank cashiers, who must always be available to serve their clients:

'People don't believe that in the civil service people come to work at 7 [am] and leave at $10 \mathrm{pm} . .$. but the Ministry of Finance is different. Even in the budget division that I say their work is routinized, you are the bank, you are the cashier. So, there might be a request that is very urgent and so you need to be around because you never know when the request will come and it will be in your schedule to deliver. So, you find people come in very early and leave very late. ${ }^{27}$

We found evidence in support of Grindle's (1997: 488) observations that civil servants in high-performing agencies often feel a sense of 'prestige [and a] reputation for intelligence and professionalism' in working for their organisations. Some respondents explained their attitude to work and the generally positive organisational culture in the MoF in terms of 'a sense of commitment to making a difference', ${ }^{28}$ and the prestige associated with working with the Ministry. For example, asked what motivates staff to stay with the Ministry despite the low levels of remunerations (see below), one respondent stated that 'it is the privilege; the fact that you work with Finance makes you highly respected ${ }^{29}$

Many specifically referred to their inputs into the national budget statement as an important source of pride that in turn motivates their performance. One unit head responded to our question about the factors that motivate his performance by simply showing us a hard copy of the budget statement, noting that:

\footnotetext{
${ }^{26}$ Former MoF official, 24 May 2018.

${ }^{27}$ MoF director, 8 June 2018.

${ }^{28}$ MoF head of unit, 22 May 2018.

${ }^{29}$ Former MoF official, 24 May 2018.
} 
'anybody who contributed to this feels proud to be part of the MoF ... Anything that the government spends is through the budget statement .... So, you feel satisfied that you are making a great impact. ${ }^{, 30}$

Thus, although there are generally no financial incentives to perform, the prestige of participating in managing the economy remains a key motivating factor for many employees. In fact, as we show below, such expectations motivate young graduates to work for the Ministry on a voluntary basis, with hopes of gaining full-time employment there in the future.

\subsection{Staff incentives and performance}

While Roll highlighted the importance of a good remuneration system for the emergence and persistence of PoEs (Roll, 2014a: 203; 2014b: 381), salary levels 'did not strongly differentiate' between the high- and low-performing state agencies analysed by Grindle (1997: 484). In the Ghanaian context, Owusu (2006a) identifies pay-scale as one of two crucial factors that account for differences in the performance of public organisations, and goes on to conclude elsewhere that 'reforming the incentive system is a prerequisite for cultural change' (Owusu, 2012: 148). Our findings challenge this claim. With remunerations based on the regular civil service pay-scale, salaries of MoF staff are low, not only in relation to other public organisations performing similar tasks, but also in relation to those of special/technical advisors recruited into the Ministry. Indeed, nearly all interviewees within the Ministry echoed the statement that they work there 'despite the low salary levels' ${ }^{31}$ Insiders regularly compared their salaries to those working with the Bank of Ghana (BoG), the Ghana Revenue Authority (GRA) and the Volta River Authority (VRA), describing their own take-home pay as 'peanuts', 'very ridiculous', or 'unfair'.

Importantly, and perhaps in recognition of the meagre salaries of staff, 'special/technical advisors' recruited into the Ministry are often put on the payroll of the GRA, deepening the feelings of 'unfairness' and resentment among bureaucrats. Some civil servants expressed the view that they do most of the Ministry's work and therefore find it difficult to understand why so-called technical advisors would deserve better incentives than even bureaucratic heads such as directors:

'Look, my director has 25 years of experience [but] he doesn't earn what these special advisors are earning. ... they are sending some kind of signal that there is even no use in rising through the ranks and being a director. ${ }^{32}$

While some junior staff complained that the limited available incentives for staff (e.g. accommodation, car and fuel allowance) tend to be skewed towards those at higher levels, directors themselves feel poorly paid, at least in comparative terms:

\footnotetext{
${ }^{30}$ MoF official, 22 May 22, 2018.

${ }^{31}$ MoF official, 16 May 2018.

${ }^{32}$ MoF principal official, 31 May 2018.
} 
'If you take the GRA, we work with them, but their conditions of service are very different from ours. We work with Bank of Ghana in managing the economy, but what Bank of Ghana staff take is way above the Ministry and these are people who we sit in the same meetings. ${ }^{33}$

However, in recognition of the specialised nature of their work, staff of the Ministry do receive a special duty allowance on an annual basis. Yet the impact of these allowances on staff motivation and performance, and by extension the relative effectiveness of the Ministry, are likely to be limited. First, this allowance is not based on performance, but is an automatic entitlement for all those working with the Ministry. Second, with this allowance computed on the basis of annual salary (15 percent of salary), its utility value and impact on staff motivation would be low, given the generally low levels of salaries described above.

Importantly, the working environment within the Ministry is not enticing either, with some young officers reportedly working without computers for a couple of months at some point:

'when you are recruited, it is very difficult to get a computer to work with, but as time goes on, and when the Ministry procures some and they are enough, you may get. ${ }^{34}$

'When I joined, we were like six or seven in a room with just like two computers. So... we were all going in turns.' 35

While insiders attributed the problem of limited equipment to long procurement processes, one donor representative noted a tendency for senior officials to prioritise the provision of vehicles for themselves at the expense of basic equipment for younger officers who do much of the actual analytical work. ${ }^{36}$ However, another donor representative noted that access to relevant infrastructure and the general environment within the MoF is of much better quality than what pertains in the wider public sector. That said, he added that, judged by international standards, the Ministry's overall working environment is 'depressing', stating further that its staff 'don't look so motivated: you see, when I walk into a bank or a mobile phone company [in Ghana], I see more drive'. ${ }^{37}$ Overall, then, the MoF's relatively good performance cannot be explained in terms of higher wages and salaries.

In the context of these low salary levels and the less-than-impressive working environment, we found that staff motivation in the Ministry is underpinned by several indirect personal benefits that give staff job satisfaction. These benefits include international networking opportunities, mainly through donor-funded capacity-building

\footnotetext{
${ }^{33}$ Senior MoF director, 8 June 2018.

${ }^{34} \mathrm{MoF}$ female FGD participant, 22 May 2018.

${ }^{35}$ MoF male FGD participant, 22 May 2018.

${ }^{36}$ Donor representative, 9 May 2018.

${ }^{37}$ Donor representative, 18 April 2018.
} 
programmes aimed at junior and middle-level bureaucrats, but also for those in management positions. Explaining the basis of his job satisfaction, one senior official stated:

'apart from your pay, you are working in an institution where there is a lot of networking: I am meeting donors, I am meeting a lot of high-ranking officials everywhere, the whole world, not just in Ghana. ${ }^{38}$

Both management and staff concur that one of the biggest benefits in the Ministry is access to capacity-building opportunities. Key informants noted that, through the support of donors, the capacity of staff is constantly being built: 'Every single term, they are going for one course or the other .... the average number of times each of them has gone for a training programme will be probably four'. ${ }^{39}$

Although several other respondents identified opportunities for acquiring higher degrees among the factors that motivate them, two important caveats are worth noting. First, unlike in the past, the Ministry does not have a structured capacitybuilding programme - a problem often attributed to limited resources and the large and growing number of staff. ${ }^{40}$ Consequently, and depending partly on donor interests, opportunities for further training vary greatly across divisions and units, and individuals' access to them is a 'scramble', ${ }^{41}$ based partly on 'how you are connected'. ${ }^{42}$ Second, the impact of such opportunities on staff motivation and performance is mixed. Bound by civil service rules that require staff to work for a specific number of years, ${ }^{43}$ career progression is more about longevity than academic qualification and performance. In this respect, going for further studies does not, on its own, contribute to one's career progression, nor does it result in salary increases:

'I left to go and do my Masters in 2011 and this was an opportunity that the Ministry provided .... But we came back and were rather penalised. So, my year group, those that stayed behind and could not go to school, are now two years ahead of me in terms of progression. ${ }^{, 4}$

In this context, leaving for further studies arguably tends to derail one's career progression. Nevertheless, one respondent distinguished between administrative

\footnotetext{
${ }^{38}$ Senior MoF official, 16 May 2018.

${ }^{39}$ MoF divisional director, 16 May 2018.

${ }^{40}$ One respondent stated that, in the past, once you entered the Ministry, there was a structured capacity-building programme that enabled people to study for Masters degrees (MoF director, 8 June 2018).

${ }^{41}$ MoF head of unit, 17 May 2018.

${ }^{42}$ MoF director, 8 June 2018.

${ }^{43}$ Staff are required to spend a minimum of three years before being eligible for promotion from one grade to the next. However, promotion to the position of a chief economics officer (which is a director-level position) usually takes much longer, depending principally on the availability of a vacancy at the top.

${ }^{44}$ MoF head of unit, 17 May 2018.
} 
recognition and technical recognition within the Ministry's working environment and noted that going for further studies motivates staff by contributing to their technical recognition, by which is meant being assigned higher-level technical responsibilities. For this respondent, this form of 'technical recognition' is an important motivating factor, because:

'Functionally, you perform the high-level technocratic jobs commensurate with your qualification, but administratively you are far behind the ladder. So, at the technical level, there is some recognition: you do high-level work, you attend cabinet meetings etc. .... That is what has kept some of us here, because we have been given some responsibilities that we thought is quite challenging. ${ }^{45}$

In this context, it would seem that improved salaries are neither a necessary nor a sufficient condition for building effective public sector organisations. Instead, our evidence supports Grindle's (1997) observations regarding the limited explanatory power of enhanced compensation for the emergence of exceptionally well performing organisations in hostile environments. In fact, one recent quantitative study on Ghana and Nigeria confirms these observations and goes further, to caution that 'the focus of civil service reforms worldwide on introducing stronger incentives could backfire' (Rasul et al., 2017a; 2017b).

\subsection{Operational autonomy and staff discipline}

A common feature of PoEs is their possession of sufficient operational autonomy that enables them to control personnel and rewards (Grindle, 1997; Roll, 2014a; McDonnell, 2017; Rasul et al., 2017a; 2017b). Operational autonomy not only allows organisations to attract the skilled and committed personnel they identify through their recruitment processes (McDonnell, 2017: 504), but also allows organisations to set performance standards for their employees and hold them accountable for meeting those standards (Grindle, 1997: 488).

The MoF's control over the promotion of its staff is confined primarily to completion of annual appraisal forms that are graded by their line directors for onward submission to the OHCS (Office of Head of Civil Service), which then determines the fate of candidates based on oral interviews. With promotions determined largely by the OHCS, the Ministry's staff sometimes remain in a particular grade principally because the OHCS is unable to organise promotion interviews. Despite being subject to civil service rules, our research draws attention to various ways in which the MoF is able to exercise quasi-autonomous powers over its personnel, including the capacity to poach brilliant graduates. Even after the list of new recruits from the OHCS is circulated, the most proactive divisional directors are able to tactfully refuse staff that do not meet particular standards, preferring to wait until they are able to attract the right calibre of staff.

${ }^{45}$ Ibid. 
While the capacity to sanction poorly performing employees is recognised as an important management style for improving organisational productivity (Grindle, 1997: 487), neither the chief director nor divisional directors have formal powers to sanction MoF staff. Moreover, as in other developing countries, legal provisions and cultural norms make it exceedingly difficult to terminate the employment of a civil servant in Ghana (McDonnell, 2017). Nevertheless, the MoF is able to exercise significant control over personnel behaviour, mainly through the practice of staff reassignments across divisions.

Employee reassignments are quite frequent in the Ministry, with respondents generally speaking about this practice in negative terms, seeing it as a subtle way of punishing non-performance and dealing with other perceived 'deviant' behaviours. One respondent told us that he has had 'the misfortune' of being reassigned to four divisions since joining the Ministry. Asked why he considers his experience as a misfortune, he responded that, 'in this Ministry, when you are moved around so much, then you are seen to be causing trouble or something'. ${ }^{46}$ Others spoke of the 'psychological trauma' or 'emotional effects' that accompany such moves, not least as affected employees are rarely given any prior information about their reassignments. $^{47}$

The impact of such 'targeted' reassignments is not always positive for organisational productivity, not least as it can undermine the professional development of staff in terms of specialisation, and in some cases render staff quite redundant in their reassigned divisions. Nevertheless, fearing that non-performance can result in one's reassignment, this practice also seems to exert pressure on employees to enhance their commitment and loyalty to management in ways that contribute to productivity.

Roll (2014a: 210) emphasised the importance of political management - the various informal activities adopted by leadership to influence decisions and conditions that enable the organisation to maintain or increase its effectiveness - for sustaining PoEs. In the case of the MoF, these informal activities ranged from poaching brilliant graduates, adopting innovative means of rewarding performance through the strategic allocation of training opportunities, and leveraging political capital in the refusal and reassignment of staff. For example, to be politically tactful, divisional heads often lobbied behind the scenes to gain the chief director's permission before the reassignment of staff (see McDonnell, 2017). Such observations also confirm Roll's argument that in contexts of personalised forms of governance, relatively effective public sector agencies try to gain organisational autonomy not by isolating themselves from politics, but instead by cultivating 'strong political relations' and engaging in 'political bargaining' (Roll, 2014a: 213) with powerful political and bureaucratic elites.

\footnotetext{
${ }^{46}$ MoF principal economic officer and head of unit, 22 May 2018

${ }^{47}$ MoF principal economic officers, 30-31 May 2018.
} 


\subsection{Conclusion}

Our study identified four particular periods of relatively high performance: the early to mid-1950s, during the ministerial leadership of Komla Gbedemah; the PNDC ruling coalition (1984-1992) under the ministerial leadership of Kwesi Botchwey; the first term of the NPP-led ruling coalition (2001-2004), when Osafo Maafo was finance minister; and, to a limited extent, the period from 2013 to 2016, under the leadership of Seth Terkper as finance minister. Performance was at its lowest from the early 1960s up until 1983, followed by the Rawlings-led NDC ruling coalitions that governed from the immediate period after the return to multiparty democracy in 1992 until its electoral defeat in the December 2000 elections.

In line with the existing PoE literature, we find that a number of internal organisational factors do play a role in understanding why the MoF has remained a relatively high performer within the Ghanaian public bureaucracy. This includes a relatively positive organisational culture, in terms of the time spent on task by most staff, as well as a high sense of organisational identity among staff. Partly as a result of the specific and time-bound nature of most of the Ministry's deliverables, as well as the importance of its mandate for the wider economy and the state, staff attitudes to work in the Ministry are generally more positive than the wider civil service. While salary levels remain generally low, most staff remain highly motivated, due to various indirect personal benefits (e.g. training and international networking opportunities), and the prestige associated with working with the Ministry. These observations provide support for Dilulio's arguments that creating capable public organisations

'has less to do with ... fine-tuning pay scales, or referring intra-or interbureaucratic battles, and more to do with establishing social and moral reward systems that make it possible for government agencies to tap the creativity, sense of duty, and public-spiritedness of their workers'. (Dilulio, 1994: 315).

However, findings show that variations in performance over time are strongly explained by changes in Ghana's political settlements dynamics, as summarised in Table 3. In particular, we find strong support for the theoretical proposition that PoEs are more likely to emerge and endure under dominant political settlements than in countries characterised by competitive clientelism, due to the varied degrees of elite vulnerability under these settlement types and the extent to which this shapes elite incentives in investing in bureaucratic capacities in the long term (see Whitfield et al., 2015; Hickey, 2019. Under the dominant leader type of PS in the 1980s, successful macroeconomic reforms were facilitated by three key factors, all of which were directly underpinned by the dominant character of the political settlement at the time. First, 'the state's insulation from society and its capacity to resist interest group demands' (Chazan, 1991) enabled it to undertake difficult economic reforms that previous ruling coalitions were unable to implement, due to their vulnerability in power. Second, unlike previous ruling coalitions who, in an attempt to manage their vulnerabilities, regularly meddled in the economic policy-making processes of their 
finance ministers, this period marked 'the reassertion of a measure of autonomy' (Chazan, 1991) by technically competent macroeconomic bureaucrats who had the strong backing of the president. Third, this team of technocrats was in charge of managing the economy for a prolonged period of time, allowing for policy continuity, credibility with donors, and implementation experience.

The return to competitive clientelism in late 1992 somewhat undermined the effectiveness of the MoF to implement and sustain economic reforms, and by extension undermined the state's macro-economic management capacity. The two key causal mechanisms through which performance is undermined are the politicisation of bureaucratic appointments and the phenomenon of political business cycles. First, under the current competitive clientelist PS, the political loyalty of bureaucrats tends to take precedence over technocratic expertise in shaping the appointments of senior management. Consequently, during political transitions, chief directors and some other people in senior management positions are often replaced with new appointees whom the new political leadership can 'trust', not necessarily in terms of technocratic expertise, but mainly in terms of their political loyalty. This practice has had adverse implications for PFM reforms and for the performance of the MoF in various ways. Second, government's spending often significantly exceeds both domestic revenue outturns and annual spending ceilings in election years, resulting in persistently high levels of fiscal deficits, increasing levels of inflationary financing and growing public debt (Asiamah et al., 2014). However, the fact that these fiscal deficits are often brought down during the two years following elections implies that the persistent problem of budget overruns arises mainly from bureaucrats' weak capacity in resisting political pressures against election-induced expenditures, rather than the absence of sufficient technocratic expertise among MoF bureaucrats for addressing them. The Finance Ministry has recently championed important reforms aimed at addressing these problems, including the passage of a new PFM Act in 2016, and in devising new regulations aimed at capping the fiscal deficit at a maximum of 5 percent of GDP from 2018 onwards. However, whether these efforts will succeed in avoiding the recurrent buildup of fiscal pressures along electoral cycles can best be assessed after the next elections in December 2020.

Overall, the periods of high performance we have identified here tend to share three main characteristics. The first is the relative longevity in ministerial leadership. This was especially the case during the dominant ruling coalition of the PNDC, when Kwesi Botchwey remained in Finance for a 10-year period. Komala Gbedemah, Osafo Maafo and Seth Terkper all served for a period of four years. In contrast, between 1957 (when Gbedemah left office) and 1982 (when Kwesi Botchwey became finance minister), there were at least 10 finance ministers, translating into an average of less than three years per minister. That these periods also witnessed the worst macroeconomic indicators in Ghana would seem to suggest that longevity in ministerial leadership matters for performance. 
The second factor relates to the nature of ministerial leadership. Whether during the first few years of Nkrumah's rule, during the structural adjustment reforms, or in the period from 2001-2005 and 2013-2016, the ability of ministers to resist political pressures and engage in effective political bargaining was central to successful reforms and enhancing organisational performance. Importantly, each of the ministers during this period was more of a 'technopol' than a technocrat, in that their ability to push through reforms was driven not only by their possession of needed technocratic expertise, but also by virtue of their strong political influence within the ruling coalition. These findings support recent observations that in contexts of personalised forms of governance, public sector agencies can enhance their effectiveness, not by isolating themselves from politics, but instead by cultivating 'strong political relations' and engaging in various forms of 'political bargaining' with powerful political and bureaucratic elites (Roll, 2014a: 213; see also Leonard, 2010).

Third, and reflecting the transnationalised character of Ghana's political settlement, the influence of donors was crucial. This was especially so during the SAPs era in the 1980s and the period of HIPC debt relief during 2001-2005. However, as our findings also reveal, it is neither the quantum of aid nor the strength of aid conditionalities that matter in shaping the impact of external development assistance, but instead the extent to which the interests/incentives of domestic and transnational elites are aligned. As our findings show, the significant macroeconomic weaknesses that occurred during 2010-2012 coincided with a period when donors' budget support disbursement 'plateaued at a high level' (EU Development and Cooperation, 2017b: 15). At the same time, the significant off-budget expenditures that took place towards the 2012 elections, and which significantly undermined macroeconomic stability, occurred amidst an IMF Extended Credit Facility that had structural benchmarks (including quantitative targets on the nominal budget deficit, foreign exchange reserves and reduction of arrears) aimed at reducing budget deviations and improving fiscal reporting (EU Development and Cooperation, 2017a: 68). However, that the exigencies of the 2012 elections undermined the effectiveness of these donor efforts is illustrative of the limits of external actors in pushing for reforms that appear to be at variance with the interest of domestic political elites. 


\section{References}

Abdulai, A.-G. and Hickey, S. (2016). 'The politics of development under competitive clientelism: Insights from Ghana's education sector'. African Affairs 115(458): 44-72.

Abdulai, A.-G. and Hulme, D. (2015). 'The politics of regional inequality in Ghana; State elites, donors and PRSPs', Development Policy Review 33(5): 529553.

Africa Confidential, (2016). 'It is the contract election'. 6 March. Available at: https://www.africa-confidential.com/article/id/11540/It's the contract electio (accessed 3 June 2019).

Allen, R., Hurcan, Y., Murphy, P., Queyranne, M., and Ylaoutinen, S. (2015). 'The evolving functions and organization of finance ministries'. IMF Working Paper WP/15/232. Washington DC: International Monetary Fund.

Anaman, K. A. (2016). 'Impact of democratic political transition on the economy of Ghana'. In K. A. Ninsi (ed.), Issues in Ghana's Electoral Politics. Dakar: Council for the Development of Social Science Research in Africa. Dakar: Council for the Development of Social Science Research in Africa (CODESRIA), pp. 135-151.

Ansu, Y. (2013). 'Industrial policy and economic tTransformation in Africa: Strategies for development and a research agenda'. In J. E. Stiglitz, J. L. Yifu, and E. Patel (eds.), The Industrial Policy Revolution II: African in the Twenty-first Century. Basingstoke: Palgrave Macmillan.

Asiamah, J., Akosah, N. and Owusu-Afriyie, E. (2014). 'An assessment of fiscal sustainability in Ghana'. Bank of Ghana Research Working Paper, WP/BOG-2014/09. Accra: Bank of Ghana.

Ayee, J. (2013). 'Public administrators under democratic governance in Ghana'. Internal Journal of Public Administration 36(6): 440-452.

Ayee, J. R. A. (2008). 'Some thoughts on ministerial reshuffles in Ghana'. Paper delivered at the Ghana Academy of Arts and Sciences. British Council, Accra, 8 May.

Bebbington, A., Abdulai, A.-G., Bebbington, D., Hinfelaar, M. and Sanborn, C. (2018). Governing Extractive Industries: Politics, Histories, Ideas. Oxford: Oxford University Press.

Berry, S. (2008). 'Ancestral property: Land, politics and "the deeds of the ancestors" in Ghana and Côte d'Ivoire'. In J. M. Ubink and K. S. Amanor (eds.), Contesting Land and Custom in Ghana: State, Chief and the Citizen. Leiden: Leiden University Press, pp. 27-53.

Betley, M., Bird, A. and Ghartey, A. (2012). Evaluation of Public Financial Management Reform in Ghana, 2001-2010. Final Country Case Study Report. Joint Evaluation 2012:8. Stockholm: SIDA.

Chazan, N. (1991). 'The political transformation of Ghana under the PNDC'. In D. Rothchild (ed.), Ghana: The Political Economy of Recovery. Boulder, CO and London: Lynne Rienner Publishers, pp. 21-47.

Debrah, E. (2009). 'The economy and regime change in Ghana, 1992-2004'. Ghana Social Science Journal, 5\&6 (1\&2): 84-113. 
Dilulio, J. D. (1994). 'Principal agents: The cultural bases of behavior in Federal Government bureaucracy'. Journal of Public Administration Research and Theory 4: 277-318.

EU Development and Cooperation (2017a). Joint Evaluation of Budget Support to Ghana (2005-2015). Final Report, Volume 2a. Particip $\mathrm{GmbH}$ in collaboration with IEG, June.

EU Development and Cooperation (2017b). Joint Evaluation of Budget Support to Ghana (2005-2015). Final Report, Volume 1. Particip GmbH in collaboration with IEG, June.

Fyson, S. (2009). 'Sending in the consultants: Development agencies, the private sector and the reform of public finance in low-income countries'. International Journal of Public Policy 4(3/4): 314-343.

Gbana, N. I. (2014). 'In defence of Seth Terkper'. GhanaWeb 22 January. Available at: $\quad$ https://www.ghanaweb.com/GhanaHomePage/features/In-defence-ofSeth-Terkper-298508 accessed June 12, 2019

Ghana Statistical Service (2017). Ghana Living Standards Survey Round 7 (GLSS 7): Poverty Trends in Ghana, 2005-2017. Accra: Ghana Statistical Service.

Government of Ghana (2018). Public Expenditure and Financial Accountability (PEFA) Performance Assessment Report. Final Report. 25 September. Washington, DC: The World Bank.

Green, D. (1995). 'Ghana's "adjusted" democracy', Review of African Political Economy, 22(66): 577-585.

Grindle, M. S. (2012). Jobs for the Boys: Patronage and the State in Comparative Perspective. Cambridge, MA: Harvard University Press.

Grindle, M. (1997). 'Divergent cultures? When public organizations perform well in developing countries'. World Development 25(4): 481-495.

Hickey, S. (2019). 'The politics of state capacity and development in Africa: Reframing and researching "pockets of effectiveness"'. ESID Working Paper No. 117. Manchester, UK: The University of Manchester.

Hickey, S., Abdulai, A.-G., Izama, A. and Mohan, G. (2015). 'The politics of governing oil effectively: A comparative study of two new oil-rich states in Africa'. ESID Working Paper 54. Manchester: Effective States and Inclusive Development Research Centre, The University of Manchester.

Hutchful, E. (2002). Ghana's Adjustment Experience: The Paradox of Reform. Melton, UK: James Currey

Hutchful, E. (1997). 'The institutional and political framework of macro-economic management in Ghana'. UNRISD Discussion Paper 82 Geneva: UNRISD

IMANI Center for Policy and Education (2018). 'Assessing Ghana's performance on governance using the Mo Ibrahim Index of African Governance (IIAG)'. Accra: IMANI.

IMF (1998). 'Ghana - Enhanced structural adjustment facility economic and financial policy framework paper, 1998-2000'. Washington, DC: International Monetary Fund. 
International Budget Partnership (2008). Open budget index 2008: Ghana'. Available at: https://www.internationalbudget.org/wpcontent/uploads/2011/04/cs ghana.pdf (accessed 3 June 2019).

International Budget Partnership (2010). Open budget index 2010: Ghana'. Available at: https://www.internationalbudget.org/wp-content/uploads/2011/04/OBI2010Ghana.pdf (accessed 3 June 2019).

Jeong, H.-W. (1998). 'Economic reform and democratic transition in Ghana'. World Affairs 160(4): 218-230.

Johnson, M. C. (2015). 'Donor requirements and pockets of effectiveness in Senegal's bureaucracy'. Development Policy Review 33(6): 783-804.

Khan, M. (2010). 'Political settlements and the governance of growth-enhancing institutions'. Mimeo. London: SOAS.

Killick, T. (2008). 'What drives change in Ghana? A political-economy view of economic prospects'. In E. Aryeetey and R. Kanbur (eds.), Economy of Ghana: Analytical Perspectives on Stability, Growth and Poverty. Oxford: James Currey, pp.20-34.

Killick, T. (2010). Development Economics in Action: A Study of Economic Policies in Ghana. Second Edition. London: Routeledge.

Lawson, A. (2012). Evaluation of Public Financial Management Reform. Burkina Faso, Ghana and Malawi 2001-2010. Final Synthesis Report. Stockholm: Sida.

Leite, S. P., Pellechio, A., Zanforlin, L., Begashaw, G., Fabrizio, S. and Harnack, J. (2000). 'Ghana: Economic development in a democratic environment'. IMF Ocassional Paper 199. Washington, DC: International Monetary Fund.

Leonard, D. K. (2010). "Pockets" of effective agencies in weak governance states: Where are they likely and why does it matter?' Public Administration and Development 30:91-101.

Levy, B. (2014). Working with the Grain:Integrating Governance and Growth in Development Strategies. Oxford: Oxford University Press.

Lyon, T. (1997). 'Ghana's encouraging elections: A major step forward'. Journal of Democracy, 8(2): 65-77

McDonnell, E. M. (2017). 'Patchwork leviathan: How pockets of bureaucratic governance flourish within institutionally diverse developing states'. American Sociological Review 82(3): 476-510.

Molini, V., and Paci, P. (2015). Poverty Reduction in Ghana: Progress and Challenges. Washington, DC: World Bank.

Mosley, P. and Chiripanhura, B. (2016). 'The African political business cycle: Varieties of experience'. Journal of Development Studies, 52(27): 917-932.

Ninsin, K. A. (1991). 'The PNDC and the problem of legitimacy'. In D. Rothchild (ed.), Ghana: The Political Economy of Recovery. Boulder, CO and London: Lynne Rienner Publishers, pp.49-67.

Opoku, D. K. (2010). The Politics of Government-Business Relations in Ghana, 1982-2008. New York: Palgrave Macmillan. 
Osei, R. D. and Telli, H. (2017). 'Sixty years of fiscal policy in Ghana'. In E. Aryeetey and R. Kanbur (eds.), The Economy of Ghana Sixty Years after Independence. Oxford: Oxford University Press, pp.66-73.

Osei, R. D., Asem, F. and Domfe, G. (2013). 'The political economy dimensions of macroeconomic management of aid in Ghana'. WIDER Working Paper No. 2013/106. Helsinki: UNUWIDER.

Owusu, F. Y. (2012). 'Organizational culture and public sector reforms in a postWashington consensus era: Lessons from Ghana's good reformers'. Progress in Development Studies 12 (2\&3): 135-151.

Owusu, F. (2006a). 'Differences in the performance of public organisations in Ghana: Implications for public-sector reform policy'. Development Policy Review, 24(6): 693-705.

Owusu, F. (2006b). 'On public organizations in Ghana: What differentiates good performers from poor performers? African Development Review, 18(3): 471485.

Rasul, I., Rogger, D. and Williams, M. J. (2017a). 'Management and bureaucratic effectiveness: A scientific replication in Ghana and Nigeria'. Policy Brief 33301. London: International Growth Centre.

Rasul, I., Rogger, D. and Williams, M. J. (2017b). 'Management and bureaucratic effectiveness: A scientific replication in Ghana and Nigeria'. Final Report S33301-GHA-1. London: International Growth Centre.

Republic of Ghana (2003). The Budget Statement and Economic Policy of the Government of Ghana for the 2004 Financial Year. Accra: Ministry of Finance and Economic Planning.

Resnick, D. (2016). 'Strong democracy, weak state: The political economy of Ghana's stalled structural transformation'. IFPRI Discussion Paper 01574. Washington, DC: International Food Policy Research Institute.

Rimmer, D. (1990). Staying Poor: Ghana's Political Economy, 1950-1990. Oxford, Newyork, Seoul, Tokyo: Pergamon Press.

Roll, M. (2014a). The Politics of Public Sector Performance: Pockets of Effectiveness in Developing Countries. New York: Routledge.

Roll, M. (2014b). 'The state that works: A "pocket of effectiveness" perspective on Nigeria and beyond'. In T. Beirschenk and J.-P. Olivier de Sardan (eds.), States at Work: Dynamics of African Bureaucracies. Leiden: Brill, pp. 365397.

Silverio, M. J. and Maddalena, H. (2016). Ghana-Social Protection Assessment and Public Expenditure Review. Washington, DC: World Bank Group

Tignor, R. (2006). W. Arthur Lewis and the Birth of Development Economics. Princeton, NJ: Princeton University Press.

Tsikata, Y. M. (2001). 'Owning economic reforms: A comparative study of Ghana and Tanzania'. WIDER Discussion Paper No. 2001/53. Helsinki: United Nations University, World Institute for Development Economics Research.

Whitfield, L. (2010). 'The state elite, PRSPs and policy implementation in aiddependent Ghana'. Third World Quarterly, 31(5): 721-737. 
Whitfield, L. (2018). Economies after Colonialism: Ghana and the Struggle for Power. Cambridge: Cambridge University Press.

Whitfield, L., Therkildsen, O., Buur, L. and Kjær, A. M. (2015). The Politics of African Industrial Policy: A Comparative Perspective. Cambridge: Cambridge University Press.

World Bank (1993). Program Performance Audit Report: Ghana First and Second Structural Adjustment Credits. Washington, DC: World Bank.

World Bank (2011). Ghana - Joint Review of Public Expenditure and Financial Management. Washington, DC: World Bank 
Appendix I: Performance on revenue mobilisation for selected countries

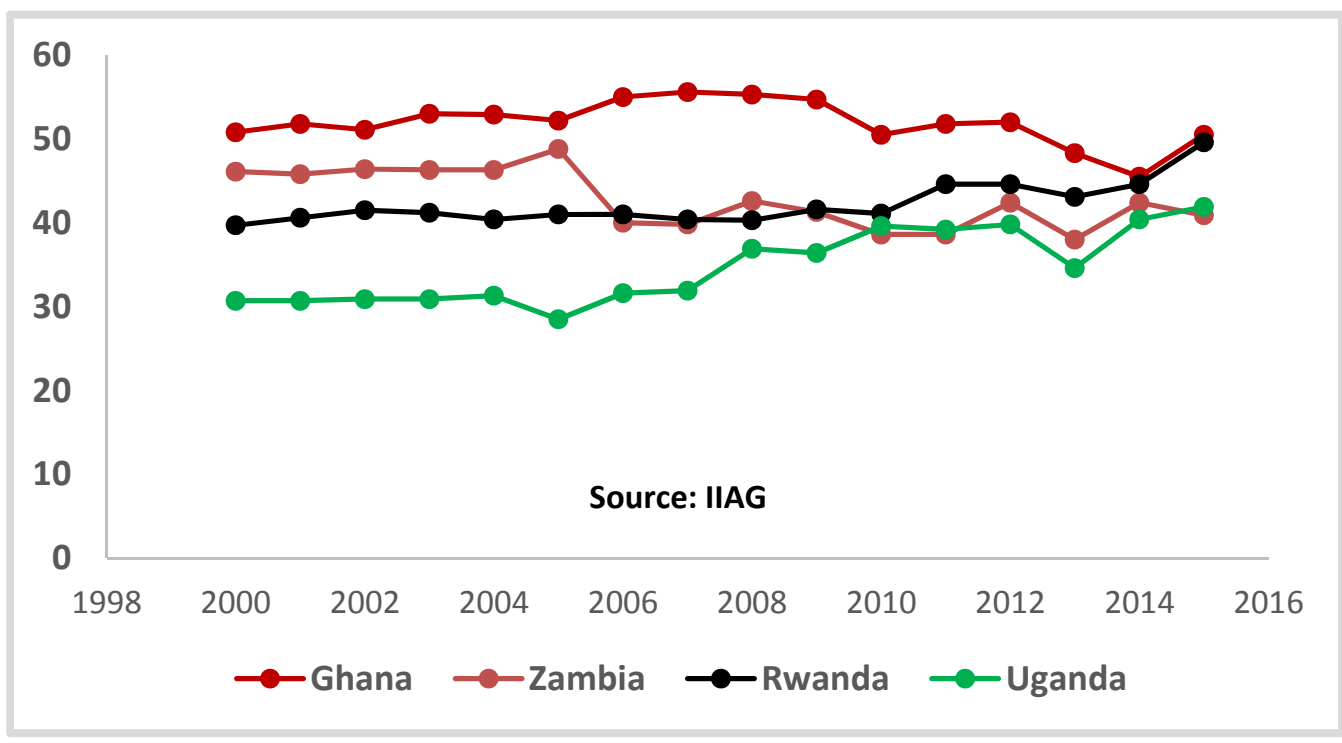

Appendix II: State effectiveness: survey results $(\mathrm{N}=27)$

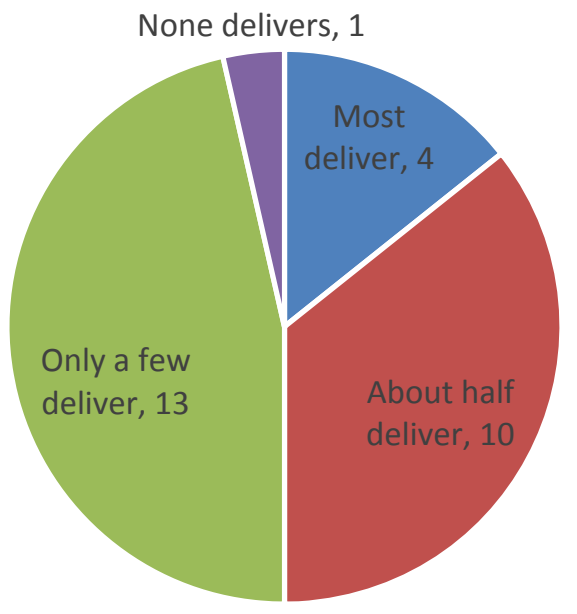




\section{esid}

\section{The Effective States and Inclusive Development Research Centre}

The Effective States and Inclusive Development Research Centre (ESID) aims to improve the use of governance research evidence in decision-making. Our key focus is on the role of state effectiveness and elite commitment in achieving inclusive development and social justice.

ESID is a partnership of highly reputed research and policy institutes based in Africa, Asia, Europe and North America. The lead institution is the University of Manchester.

The other institutional partners are:

- $\quad$ BRAC Institute of Governance and Development, BRAC University, Dhaka

- $\quad$ Center for Democratic Development, Accra

- $\quad$ Center for International Development, Harvard University, Boston

- Department of Political and Administrative Studies, University of Malawi, Zomba

- $\quad$ Graduate School of Development, Policy \& Practice, Cape Town University

- Institute for Economic Growth, Delhi

In addition to its institutional partners, ESID has established a network of leading research collaborators and policy/uptake experts. 